NBER WORKING PAPERS SERIES

\title{
THE MEANING OF COLLEGE IN THE LIVES OF AMERICAN WOMEN: THE PAST ONE-HUNDRED YEARS
}

Claudia Goldin

Working Paper No. 4099

\author{
NATIONAL BUREAU OF ECONOMIC RESEARCH \\ 1050 Massachusetts Avenue \\ Cambridge, MA 02138 \\ June 1992
}

I thank Boris Simkovich for providing extraordinary research assistance. Kathy Snead collected the Women's Bureau data relating to Bulletin No. 292 under the auspices of PARSS at the University of Pennsylvania. The comments and suggestions of Lawrence F. Katz and Ceci Rouse are appreciated. The students of Economics 1356 (Spring 1991) provided the stimulus for this study, and I thank them for their candor and insights. This paper has benefited from comments provided by participants during public lectures at Wellesley College, Bates College, Simmons College, Tufts University, and the University of Iowa. This paper was written for the Conference on Women's Human Capital and Development, May 18-22, 1992, Bellagio, Italy, and I thank the discussants, John Strauss and Barbara Torrey, as well as the other participants for their suggestions. This paper is part of NBER's research programs in Development of the American Economy and Labor Studies. Any opinions expressed are those of the author and not those of the National Bureau of Economic Research. 
NBER Working Paper \#4099

June 1992

\title{
THE MEANING OF COLLEGE IN THE LIVES OF AMERICAN WOMEN: THE PAST ONE-HUNDRED YEARS
}

\begin{abstract}
Three cohorts of college women are considered here. The first, graduating from 1900 to 1920, was faced with a choice of "family or career," while the second, graduating from 1945 to the early 1960s, opted for family and employment serially -- that is, "family then job." The third, graduating since 1980 in a climate of greater gender equality, is attempting both "family and career," with mixed results and considerable frustration. This paper assesses the reasons for the changing set of tradeoffs each generation of college women faced and why the college education of women expanded in the post-World War II era. The first cohort attended college when the numbers of men and women in college were about equal, while the second attended college when the proportion of all undergraduates who were male was at an all-time high. Only half of the return to college for the second cohort came in the form of their B.A. degrees, while the other half came from their Mrs. degrees. Ironically, because the total return to college -- from the B.A. and Mrs. degrees -- was quite high, enrollments of women expanded rapidly and eventually gave rise to a demand for greater gender equality in the labor market and society.
\end{abstract}

\author{
Claudia Goldin \\ Department of Economics \\ Harvard University \\ Cambridge, MA 02138 \\ and NBER
}


Women's education enhances gender equality and the higher education of women should enhance it even more. Yet women's experience with higher education in the United States has been a rather complex affair across the past century. Gender differences among the college educated in demographic life-course events - such as marriage and family - actually widened and then narrowed as women struggled to find the meaning of college in their lives. Gender differences in marriage rates among the college educated may be widening once again, but we have incomplete demographic histories on the most recent cohorts. ${ }^{1}$

More so than any preceding generation, college women today appear to want both family and career. The experiences of all previous cohorts serve as their guides, but none provides the example they want to follow. College women today express frustration. They have succeeded in achieving parity in numbers with their male counterparts, they are receiving educations of about equal quality, and they are continuing in professional and graduate schools in greater numbers than ever before. ${ }^{2}$ Yet full equality is still not within their reach.

I describe here the demographic and economic fates of several cohorts of college women, each a possible model for today's college woman. Tradeoffs of substantial consequence were made by each of these past generations of college women, and they are tradeoffs that the present generation seems unwilling to make. Despite the shifting tradeoffs and changing gender inequality in demographic and economic outcomes, each generation of college graduates set the stage for the next. Thus to comprehend how we arrived at the choices faced by the current generation, we must understand the full process of change from the earliest to the most recent.

\footnotetext{
1 Among college graduates 35 to 44 years old in $1989,79.4$ percent of the men but 74.9 percent of the women were currently married, spouse present. But among college graduates 25 to 34 years old in $1989,58.3$ percent of the men had already married while 68.7 percent of the women had (U.S. Bureau of the Census 1991a). Thus the 35 to 44 year old experiences speak to a widening gulf between male and female marriage rates, although the data for the younger group indicate that both men and women are marrying at very slow rates.

2 The ratio of men to women in professional schools was 23.4 in 1960 but 1.66 in 1988 . The ratio in graduate schools was 2.48 in 1960 but 0.90 in 1988 (U.S. Department of Health, Education, and Welfare, Digest 1988, OFE 1960).
} 
Because a century of experience is covered here, the focus will be on particular junctures and cohorts that span the period. I consider three generations of college graduates each about 10 to 20 years in duration, separated one from the next by 20 years. The first attended or graduated college between 1900 and 1920, the second between 1940 and 1960, and the third from about 1980 to the present.

Put starkly, the differences among them and the progression of tradeoffs have been the following. In the first -- a group graduating around 1910 and born around 1890 -- college more often than not presented a clear set of alternatives between family and career. For most women in this group it was one or the other, and when the selection was a career, it almost always involved teaching. Although college men in this generation married and had families at about the same rate as men without higher education, college women in this generation were rather different from their non-college counterparts. Approximately 50 percent of all college women either did not marny or, if they did marry, did not have children. ${ }^{3}$ College women were a small fraction of the entire college-aged population, but college men were almost as small a fraction. Although both were drawn from the upper echelons of American wealth and standing, there is evidence that differences in the demographic experiences between college women and their non-college counterparts were largely due to the "treatment effect" of college, rather than to selection bias.

In the second group - graduating around 1950 and born around 1930 -- college offered women the opportunity to have both family and paid employment. But the two were serially scheduled - family came first, in terms of timing and priority, and only after came employment. The employment of choice was, once again, teaching, for it allowed such serial timing without a large penalty. It was a profession one could "fall back on," because teaching would always be in demand and teaching credentials would remain valid. But college also afforded women in this cohort the opportunity to marry a college-educated man.

\footnotetext{
${ }^{3}$ The 50 percent figure is: 31.1 percent (never married) + [27.6 percent (having no children) $\times 68.9$ percent (ever married)].
} 
One might ask of many of the women from the second cohort whether the direct, pecuniary returns to college justified the tuition and opportunity costs of their four, or so, years of higher education. The answer would generally be that it did not, but that college allowed them to tap into the market for college-educated men. Not only did women who attended college stand a considerably higher chance of marrying a college-educated man, they also married the higher income-generating man from among the college-educated group as well as from the high-school educated group. This was also a generation that, for various reasons, became part of the American mainstream. As college became more accessible to the masses and as America became swept away by the resurgence of family, college women married and had children at almost the same rates as their non-college contemporaries. Despite all appearances to the contrary, however, the college woman of the 1950s set the stage for the events of the 1970s the resurgence of feminism.

In the third group - graduating after 1980 and born since 1960 - college appears to be offering women the opportunity for true equality with their male counterparts. College women have rejected the choice of "family or career," the options of the first cohort, and "family then job," that of the second cohort. Further, they are uncomfortable with the choice of "career then family, that of some in an intermediate cohort that just preceded them. Substantial, but not yet conclusive, evidence concerning the demographic experience of women who graduated from 1970 to 1980, now in their thirties and early forties, indicates that they tried the route of "career then family" but did not entirely succeeded at both. Many are back with the first cohort in their ex post ability to combine both successfully. ${ }^{4}$ But the third cohort considered here wants both

4 Data from U.S. Bureau of the Census (1991) indicate that 33.3 percent of 35 to 44 year old women with $>4$ years of college have not yet had a birth while 23.4 percent of those with exactly 4 years of college have not yet had at least one. Therefore women who graduated college and continued their higher education in search of a career have a much higher percentage childless than those who stopped at college graduation. The career trajectories of the group who continued after college is not known, atthough an in-depth study of one profession - that of economics doctorates - shows that women are not being promoted very rapidly (Committee on the Status of Women in the Economics Profession data). 
family and career. These women are unwilling to schedule the events serially and thereby risk not having one of them. Thus, they can find no previous cohort that provides a suitable model and only a small fraction of women within any of the cohorts that have. Many of the doors that were closed to previous generations of college women are now open. Yet the graduates of the past decade seem a discontent group. ${ }^{5}$ I have very little to say about the third cohort because it is still too young to have completed much of its demographic and employment histories.

Before considering the basis for the characterizations just offered, it is instructive to detail the percentages of males and females who attended and graduated from college across this century. The fewer women who attend college, the more they could be a highly self-selected sample from among the entire population of young women. Because I would like to isolate the "treatment effect" of college, it is imperative to understand the process of selection into college.

Prior to 1940, the proportions of men and women who attended college were low, but the percentages were remarkably similar by sex. ${ }^{6}$ Among those born from 1886 to 1895 , for example, 9.5 percent of the men attended college for at least one year while 8.9 percent of the women did, and attendance figures are approximately equal for cohorts born from 1895 to 1900 (see Figure 1). Graduation rates are somewhat further apart, where the definition of graduating college is attending for four or more years (see Figure 2). ${ }^{7}$ Of the cohort born from 1886 to 1895 , 5.0 percent of men graduated college while 3.4 percent of women did. Attendance rates were far higher for women relative to their graduation rates but only in part because two-year colleges

\footnotetext{
5 This conclusion is based, admittedly, on a small sample of students .. those in my Economics 1356 class in 1991.

${ }^{6}$ It should be noted at the very outset that in all of the empirical work that follows only white men and women are considered because of the considerably smaller number of nonwhites who attended college in the past.

7 Both the graduation rates and the attendance rates are as of ages 45 to 54 or 55 to 64 years. See Figures 1 and 2 for sources and notes.
} 
are included in the data. ${ }^{8}$ Until recently far fewer women than men who attended college actually graduated. By the cohort born in 1905, even graduation rates between the sexes had narrowed, and the ratio of graduating males to females was 1.24. This trend, however, was not to continue. The two lines in Figures 1 and 2 diverge with the cohort born around 1910, and they remain apart until the recent period. Some of the men in the cohorts born around 1920 delayed their college education during World War II, and many others would not have received a college education were it not for the war. The Gl Bill of Rights provided the first large dose of federal subsidization of college tuition and enticed a substantial fraction of men in their twenties and early thirties to return to school.

Large differences between men and women in college graduation rates persisted until the cohorts born in the 1950s. By the cohort born in 1930 the ratio of male to female graduates had increased to 1.79; by the cohort born in 1940 it had declined somewhat to 1.62 , but was still much higher than its level earlier in the century. Attendance rates differed less, in part because men, whose tuition was subsidized after World War Il, completed college at greater rates than did women and in part because women attended two-year schools in somewhat greater numbers. The gap in both graduation and attendance eventually disappeared by the cohorts born in the early 1960 s and by 1980 more women than men were recelving B.A.s per year.

Thus the first cohort being examined attended college when few men and women went to college, but at a time when they attended in roughly similar proportions to their populations. The second cohort attended college when the ratlo of males to females in attendance was greater

\footnotetext{
${ }^{8}$ In 1962, for example, two-year colleges accounted for 14 percent of all college enrollees for both males and females. Yet the ratio of graduation rates to attendance rates was 61 percent for males but 48 percent for females in the birth cohort of 1940 (see Appendix Table A1). Thus the differences in graduation rates between males and females must be accounted for by a differential graduation rate from four-year colleges. The same is probably not the case for earlier cohorts. Graduation rates were much lower for women in the cohorts born before 1905, thus graduating before about 1927. A large fraction of the women in these cohorts who attended college were in teachers' colleges and normal schools, but it is difficult to separate the two-year normal schools from the four-year teachers' colleges for those years. Normal schools are of little importance after the 1940s.
} 
than at any time in the past hundred years. Finally, the third cohort attended college in an era of the greatest gender equality in both attendance and graduation rates.

What accounted for changing male and female college attendance rates and for the shifting tradeoffs that have faced college women? The large increase of women in college beginning in the early 1950 s was due to a set of factors that increased male enrollments, decreased the age at first marriage, and enabled women to work for pay even when married. The GI Bill of Rights enabled many men to attend college who would otherwise not have been able to do so. With the influx of men in college came an influx of women, for college became a far thicker marriage market as the age at first marriage decreased and the ratio of men to women in college soared. Changes in the labor market, particularly the almost universal rescinding of the "marriage bar" - the policies of firms and school boards not to hire married women -- were crucial factors. The young woman who now wanted family could go to college, prepare for a future occupation, and find a mate. Curriculum changes within colleges had been brewing for some time but were now given greater impetus as schools strengthened programs in home economics, education, and social work, among others. Later changes were fueled, in large measure, by the women's movement, which transformed the increase in women's college attendance into a crusade for true equality. A host of factors beyond the scope of this paper led to increases in married women's employment, and as more women were spending a greater fraction of their adult lives employed, the direct returns to college increased and their college enrollments soared (see Goldin, 1990 on increased female labor force participation). Thus the rise in female college enrollment beginning in the early 1950 s was due to increases in both the direct pecuniary benefits from college as well as the indirect benefits through the marriage market.

\section{The First Cohort: Family or Career}

The first cohort studied here completed their higher education between 1900 and 1920. Although there are prior cohorts of female college graduates that might be examined, these are 
the earliest that can be studied with the data on education, occupation, fertility history, marriage age, and husband's income, among other variables, included in the 1940 Public Use Micro-Data Sample (PUMS) of the federal population census.

The first college to open its doors to women was Oberlin in 1837, but not until the 1850 s did opportunities for women in higher education expand, particularly with the establishment of female colleges. At that time, however, many of the institutions of higher learning open to women were not true colleges but were seminaries often no more intellectually demanding than high schools and without rigorous entrance requirements. Only in the 1870 s and 1880 s with the establishment of the finer women's colleges, such as Vassar and Smith, and with the opening of various state universities to women, did the era of women's hlgher education truly begin. By 1910 73 percent of all colleges were open to women, almost 80 percent of which were coeducational institutions (Newcomer 1959, p. 37). Most of the women's colleges that had minimum age requirements of sixteen years were upstanding institutions that endeavored to provide to women what other colleges were giving to men; that is they strove for equality of curriculum Woody 1929). Most colleges and universitles taught a liberal arts curriculum in which there were basically two courses of study - classical and scientific. Thus, women and men took very similar classes, even when they were not at the same institution.

In the late nineteenth century, higher education for women was justified in a variety of ways. A more educated woman would be a better wife, mother, and homemaker because a liberal arts education endowed the student with the ability to solve problems, use good judgment, and reason properly in all of life's circumstances. Further, before marriage or in its absence, the educated woman could have a career, particularly as a teacher. Finally, education promoted morality and was often combined with religious training. The wealthy and well-positioned in America often sent their sons to college, although it is not at all clear that such education enhanced their income. Thus they may have had no reluctance to send their daughters as well.

But higher education for women had what Thomas Woody, a historian of education, 
viewed as an unanticipated consequence. By the 1890 s it was clear that college women were marrying at decidedly lower rates than were those who did not attend college, and that, even if they married, they were having considerably fewer children than their lesser-educated counterparts. The finding spawned an extensive literature for it was alarming to many (see Cookingham, 1984, for references). They, and current researchers, have faced the same problem in trying to ascertain how much of the difference in demographic experiences was due to sample selection and how much was due to the treatment effect of college. Although definitive evidence on the subject has not yet been uncovered, information will be presented that is consistent with the interpretation that the differences were more a function of what college did for and to women than which women went to college.

That said, it should be noted that many of the previous studies of the nuptiality rates of college women were not based on nation-wide samples, but rather on alumni surveys. Most, but not all, of these surveys were of women in the elite colleges of the northeast, often women's colleges like Smith, Vassar, Radcliffe, Wellesley, and Bryn Mawr (see, for example, Van Kleek 1918). Not only were the studies biased in their selection of schools, often known for their low marriage rates, but marriage rates for relatively recent graduates were given with no adjustment for time since graduation. For all of these reasons the estimates in those studies were biased by virtue of composition and in terms of incompleteness of spell.

The 1940 PUMS affords a more universal view of the nuptiality of college women, although the bias here is probably in the opposite direction. By taking the recollections of older women and using the percentage who listed themselves as "never married," it is likely that the percentage who actually did marry is overstated. Among those in the cohort that would have graduated between 1898 and 1917, that is born between 1876 and 1895, more than 30 percent never married by age $45 .^{\circ}$ For those who would have graduated between 1918 and 1937, that

\footnotetext{
${ }^{2}$ I focus on college graduates to get around the problem that college attendance includes those at two-year colleges and normal schools.
} 
is born between 1896 and 1915, about 25 percent never married by age 45 (see Table 1).

The woman who attended college but did not graduate (or who graduated from a twoyear college) stood a somewhat higher probability of marrying by age 45 , but both sets of college numbers are considerably greater than are those for women who never attended college (see Appendix Table A2). The female college graduate during 1908 and 1917 was 4 times more likely to remain single than was her non-college counterpart (31.1 percent against 7.8 percent). The same statistic for the graduation classes of 1898 to 1907 is 3.7 (computed for women aged 55 to 64). College graduate women in the years from 1900 to 1927 had lifetime marriage probabilities that were fully 20 percentage points lower than their non-college counterparts.

As high as the statistics are for the percentage of college women who never married, those that aroused concern around 1900 were higher still. A survey of the members of the Association Collegiate Alumnae around 1895 revealed that only half of those in the North Atlantic region had married by age forty and slightly more, 57 percent, of those in the Middle West region had (Shinn 1895, p. 947). Just over half the graduates from the (circa) 1900 class of Mount Holyoke, Wellesley, Vassar, Radcliffe and even the University of Michigan married, although a survey of land-grant colleges revealed that about 65 percent of the graduating class of 1900 had married. ${ }^{10}$ On average, then, the data suggest that the percentage marrying in the class graduating around 1900 may have been between 50 and 60 percent. The percentage ever married began to rise in many of the schools with the graduating classes of the 1910s, consistent with the census data presented above. Thus while the overall trends in the two data sets - those of particular schools and those in the federal population census - are similar, their levels differ. The data from the 1940 PUMS reveal a higher proportion ever married, a likely consequence of the national scope of the census and the longer period of time to marriage allowed.

10 Solomon (1985, p. 120) contalns data on marriage rates for a large number of schools; Woodhouse $(1932$, p. 53) is the source for the land-grant college number. Woodhouse states that the measure is "married at the time of the survey," but the data are more consistent with "evermarried at the time of the survey." 
The general conclusion of the turn-of-the-century studies on nuptiality and college was that the college experience both caused and enabled women to have a lower marriage rate. College permitted women to be more discerning in their choice of lifestyle and husband. Further, the typical occupation for college graduate women, particularly in the East, was as a teacher in a private girls' school, and "there is no station in life (save that of a nun) so inimical to marriage as that of resident teacher in a girls' school" (Shinn 1895, p. 948). Finally, men, it was said, often disliked the intellectual woman. The possibility of sample selection or bias was raised at the time, and it was pointed out that women who considered going to college formed a biased sample because they had not married young (Newcomer 1959, pp. 212-13). But the notion that the college woman would not have married anyhow was generally, though not entirely, dismissed.

Not only did the college woman of the early twentieth century have a lower probability of marrying at some point in her life, she also stood a much higher probability of not having children even if she married. Just under 30 percent of all female college graduates who were 45 to 54 years old in 1940 recorded no lifetime births, and because their most fertile years were already past by the time of the Great Depression, their low fertility cannot be attributed to poor economic conditions. The percentage was 1.8 times that of women who had no college education and was 12.5 percentage points higher (see Table 1). Figure 3 graphs the percentage having no births by age 35 to 44 - an age group determined by the demands of the most recent data -- for college graduates, those with no college, and high-school only graduates. The percentage with no births among college graduates relative to that for women with no college was the greatest for the cohort born around 1900, yet another Indication that college graduate women at that time were more dissimilar from the general population of women than any time after. Integrating the data on marriage with that on children indicates that $\mathbf{5 0}$ percent of all female college graduates during the years 1908 to 1917 either never married or had no children by the time they reached age 45 (see Table 1).

The female college graduate around the turn of this century made a distinct choice 
between family and career. About 50 percent did not opt for husband and children, while only 22 percent of those who did not attend college took that route. The college woman of that era was 2.3 times more likely than the woman who did not attend college to take this atypical route in life. One is, therefore, led to ask what type of employment and occupations they had. Among female college graduates 45 to 54 years old in 1940 about 46 percent were in the labor force in 1940, when the rate for those with no college was about 20 percent. Yet among college graduates who married, the rate was only about 20 percent and was 16 percent for those who married and had at least one child." Labor force participation for the college graduate, as well as for the woman with no college, in 1940 was determined to a considerable extent by marital status rather than by whether she over had children (see Appendix Table A2). ${ }^{12}$ Yet it should be noted that the married college graduate had twice the probability of being in the labor force at 45 to 54 years than the married woman with no college. Thus even though the participation rates for college graduate women were depressed due to marriage, they were still considerably greater than were those for women with no college.

The vast majority of college-educated women of this cohort who were in the labor force were teachers and another substantial group were librarians, nurses, and social workers (see Table 2). Even to commentators at the time their choice of occupation was viewed as peculiar. In the words of one: "If it be asked why college women marry less than others, it may very safely be answered ... that it is not because they crave a more exciting and public life; for the majority of them are school-teachers (Shinn 1895, p. 947, emphasis in original). The professions of the first cohort were to become typical occupations in the 1950 s for educated married women with children, although in 1910 they were the occupations of the highly educated single woman. In large measure it was the presence of marriage bars that determined why single women

\footnotetext{
"Among those who married but had no children the figure is 28.4 percent (although the number of observations is only 91).

12 See Goldin (1990) on norms early in this century regarding married women's work.
} 
dominated in these fields in 1910 and it was the overthrow of the bars in the 1940s that determined why married women dominated in the 1950 s.

Thus the women in the first cohort who did not marry generally had lifetime careers as teachers, and they earned considerably more than had they not received college training. Indeed Cookingham (1984) has claimed that women in the first cohort married at far lower rates than did women in yet earlier graduating classes because career opportunities for college women expanded after 1900. The proliferation of high schools in the first few decades of this century increased the demand for college educated women just when the Progressive Era enhanced the position of the female social worker. Although we do not have a separate time series for high school teachers, the series for female public school teachers is relevant because a heightened demand for those at the secondary level is likely to raise salaries throughout the system.

The monthly salary of female public school teachers increased by 28 percent from 1900 to 1909 and by 25 percent from 1910 to 1916 , while that for postal employees increased by 10 percent during the first period and 12 percent for the second. Compared with manufacturing workers, female school teachers earned 71 percent of their monthly wage in 1900 but 89 percent in 1916. Thus the salary of female public school teachers increased relative to other white-collar workers and advanced considerably on all manufacturing workers during the period when the first cohort was graduating from college. ${ }^{13}$ It is possible, therefore, that women could go to college and become self-supporting during the early twentieth century when, by and large, they could not before. This factor adds more credibility to the notion that college had a treatment effect on the women belonging to the first cohort considered here.

Given that college women around the turn of this century had very different marriage and fertility histories from women who did not attend college and given that college men were likely to have been drawn from the same families as college women, it is instructive to examine the

\footnotetext{
${ }^{13}$ The earnings of postal workers and all manufacturing workers are from U.S. Bureau of the Census (1975) series D791 and D765-66 respectively. Monthly earnings of female public school teachers are from U.S. Bureau of Education (various years, 1900 to 1916).
} 
men's demographic fates. In 194010.2 percent of all college graduate white males 45 to 54 years old were never married or one-third the rate for women, while 11.4 percent of men in this age group with no college were never married, that is higher than the rate for college graduates. In 1950 just under 7 percent of all college graduate men, 45 to 54 years old, had never married, or almost one-quarter the rate for women. In 1960 the percentage for men was also 7 percent or one-third that for women, and in 1970 it was just under 6 percent or one-half that for women. ${ }^{14}$ The percentage of college graduate men who married by the time they reached age 45 was virtually identical to, indeed somewhat higher than, that of men with no college. Thus the marriage rate of men was virtually unaffected by college, while that for women was reduced, at times significantly.

What accounts for the fact that 50 percent of female college graduates in the first cohort either did not marry or did not have children while the figure is 22 percent for women without college? Particularly since the percentage graduating from college was very low at the time, one cannot rule out the possibility that college women were a self-selected group who would have had the same demographic fate even had they not attended college. Colleges, like Bryn Mawr, were known to have attracted young women who did not want to marry and to have provided them with a higher calling. But the percentage from the land-grant institutions who did not marry was also high. Thus the differences do not rest entirely on the type of college or the social backgrounds of the women.

The best evidence in support of the notion that college actually provided a "treatment effect" is that the percentage of female college graduates who never married fell substantially for birth cohorts that did not experience an increase in the percentage who were college graduates. If attending college involved self-selection, the underlying process would have to have changed drastically to produce this result. Figure 4 provides more complete evidence than does Table 1 on the percentage never married among college graduate women by birth cohort. A comparison

\footnotetext{
${ }^{14}$ U.S. Bureau of the Census $(1953,1966,1972)$ and the 1940 PUMS.
} 
between Figures 2 and 4 will demonstrate the point that college graduate women began to marry in more substantial numbers before the expansion of college enrollments. As Figures 4 and 5 show, the trend in marriage rates among college women looks very similar to that among noncollege women, even though the levels differ markedly.

The percentage of women who attended or who graduated college, as can be seen in Figures 1 and 2, remained constant between the birth cohorts of about 1900 and $1920 .^{15}$ But the percentage who never married began to fall sometime after the cohort born in 1890 . Despite the stability in the percentage graduating from college, the percentage never marrying plummeted from around 25 percent to 10 percent for cohorts born from 1900 to 1920 . Thus there is prima facie evidence that the demographic experiences of female college graduates changed by birth cohort before the increase in attendance and graduation rates.

Why, then, did the first cohort of college women marry at low rates and why did the rates begin to increase with subsequent cohorts? An important clue is found in what educated women, in particular educated married women, were allowed to do at the time. Educated women were, by and large, teachers, and, beginning sometime around the end of the nineteenth century, school districts adopted policies restricting the hiring of married women and firing single women who married in service. These "marriage bars" increased slowly to the 1920 s and then, with the necessity to ration jobs during the Great Depression, they escalated in the 1930s in teaching, office work, government jobs, and various other positions (Goldin 1990,1991). Many of the college women who taught when married were employed by private schools or found public school positions in some of the nation's large cities that reversed their marriage bars earlier in the century or never had such policies.

Thus for many of these college-educated women, their era left them little choice. They could marry or they could have a career in teaching, but they could not easily do both. Marriage

\footnotetext{
${ }^{15}$ I do not yet know what accounts for the sharp increase in college graduation rates, and to a lesser extent college attendance rates, with cohorts born around 1897 and whether the World War I military draft could account for the rise.
} 
bars in teaching were largely removed after 1941 when both the exigencies of the war and the, possibly related, spate of state supreme court rulings declared marriage bars to be "capricious and unjust" (see Goldin 1990, p. 170).

Note that even though the percentage of college women who never married by age 45 to 54 decreased to 22.9 percent by the cohort born around 1910, it was 5.6 percent for those who were not college educated. Although it plummeted to 7.7 percent by the cohort born around 1940, it decreased to just 3.3 percent for those with no college education (see Appendix Table A2). College women were following a trend in marriage rates that was sweeping the nation, a trend apparent in Figure 5 for non-college women. The second factor, then, to have increased the marriage rates of college women was the general increase In marriage and in family after the Great Depression. Thus college women were enabled to have both family and job and they were enticed to do so by a new norm that had, for some time, universal appeal.

\section{The Second Cohort: Family then Job}

College women in the second cohort had, therefore, joined a bandwagon. All Americans, independent of educational attainment, were marrying at their highest rates in the twentieth century (see Figure 5). But college women were not just increasing their marriage rates, they were also increasing their numbers in proportion to the female population. During the twenty-year expanse of this cohort, the graduation rate of women tripled and their attendance rate doubled. Women had followed the lead of men into college, but the increase of men was so rapid that by the end of the 1940 s men substantially outnumbered women. ${ }^{16}$ In 1925 there were as many female undergraduates as male undergraduates, and for the ten years preceding there had been

${ }^{16}$ It should be noted that World War II also affected women's presence in the academy because they were allowed to enroll in far greater numbers during the shortage of male students. Many universities, such as Harvard, even changed their rules during World War II, allowing women to take classes previously reserved for men only. 
more women than men undergraduates (see Figure 6). ${ }^{17}$ But by 1950 there were 2 men for every woman in college. Even after the peak in post-war enrollments, say in 1960, male undergraduates outnumbered female undergraduates by 1.5 to 1 . Because the statistics in Figure 6 are contemporaneous data, while those in Figures 1 and 2 are for birth cohorts, they more accurately reflect the proportions of males and females in college during a particular year.

Family, not just marriage, had taken the country by storm in the post-World War II era, and college women were not left out of this trend either. Among the college women who did marry, a far smaller percentage were not having children. About 10 percent, or a third the level for the first cohort, did not have a baby by ages 35 to 44 in the cohort born from 1926 to 1935. Thus for the second cohort, just over 18 percent were either not marrying, not having children, or both, compared with 50 percent for the previous cohort. ${ }^{18}$ College women had become part of the American mainstream in various ways. College was considerably more open to the masses, college women were marrying at a greater rate, and they were bearing far more children when married. But I emphasize that the timing of these changes is important to the argument, and that the change in marriage and fertility rates preceded the increase in college attendance and graduation rates.

As the age at first marriage declines and as the age at leaving school increases, the probability of meeting one's spouse in school increases. Among the female college graduates

\footnotetext{
${ }^{17}$ Attendance at both junior colleges and normal schools could inflate the statistics for women more than for men since both were intended for less than a four-year period. As a percentage of total undergraduate enrollment by sex, junior (or two-year) colleges have been attended by men to the same degree as women. The same was not the case for normal schools, a teachertraining program that did not culminate in a degree. Women, to a far greater extent than men, attended normal schools and state teachers' colleges, although the latter were four-year institutions. The education statistics for the pre-1940s period, however, do not conveniently separate out individuals who attended normal schools from those who attended state teachers' colleges. Data for 1929/30 indicate that among all female undergraduates in state teachers' college and normal schools only 20 percent were in normal schools. The same data also indicate that about 30 percent of all female undergraduates who began in teachers' colleges finished the four-year program and graduated (Office of Education, Biennial Survev of Education 1928/30).

${ }^{18}$ Only 8.4 percent of the ochort born from $1926-35$ had never married by age 55-64. The 18.2 percent figure is: $8.4 \%$ (never married) $+[91.6 \% \times 10.7 \%$ (no children)].
} 
in this cohort who eventually married, $\mathbf{5 7 . 2}$ percent married before or during their year of college graduation (see Table 1). College women by virtue of their age had always been in a better josition than others to meet their mate at school, but the percentage who did so was probably never higher than it was for the group graduating from around 1945 to the early 1960s. Marrying a college man - and there were large financial galns from doing so - was made far more likely through the route of college attendance.

The members of this cohort, like those in the cohort that preceded it, prepared themselves to be teachers. The percentage who were teachers in 1960 decreased slightly from that of the previous group, but was still between 50 and 60 percent. And the percentage who taught at some time in their lives must have been considerably greater. The employment rates of married women in the second cohort were not much higher than those of the previous cohort when they were young (29.6 percent versus 25.3 percent) and thus did not greatly exceed those of women who did not attend college (29.6 percent versus 26.7 percent). ${ }^{19}$ But their employment rates greatly exceeded those of women who did not attend college when both groups were older. That is, college women who married and had children were now having family and employment serially - first family and then, when their children were teenagers, employment.

The second cohort of college women was considerably more homogeneous in its demographic experience than was the first. The vast majority of the second cohort eventually married and had children, and many married quite young. Whether the direct, pecuniary returns to college were positive, and greater than some appropriate alternative rate, is a relevant issue for both cohorts. But various factors make it of overwhelming importance for the second cohort and not for the first.

The families of both the men and women who went to college around 1900 were considerably wealthier, relative to the national average, than were the families of those who went

\footnotetext{
19 The 25.3 percent figure is not really for the previous cohort but for those graduating around 1928 to 1937 , while the 29.6 percent figure is for those graduating around 1948 to 1957.
} 
to college a half century later. College for many men and women at the turn of this century. must have had a larger consumption component than anytime since. The fact that fow of the usual guides to getting-ahead, aimed at young men, mentioned college suggests that, for men at least, college had social and consumption value but little direct economic return. Thus it may not be too surprising that women and men attended and graduated from college in those years at rather similar rates. Indeed the return for women who remained in the labor force may have exceeded that for men. But we will probably never know because there are no data on income and education for that time period and certainly no data that enable a test of what incomes would have been in the absence of college.

The world of work changed considerably between the first and second cohorts of this study, and the demand for college-educated personnel surged with the proliferation of bureaucracy and more complicated technologies. Even in the absence of the GI Bill of Rights more men would have attended and graduated from college. But the GI Bill of Rights quickened the pace and served to send large numbers of men to college from older cohorts as well as from the most recent ones. Women, too, Increased their attendance and graduation rates, although, for them, the GI Bill of Rights had little affect on the previous cohorts. Note in Figures 1 and 2 that the point at which the curves turn up sharply for male cohorts precedes that for female cohorts. The difference is largely due to the fact that male cohorts born between around 1910 and 1925 were enabled to go back to school through the Gl Bill of Rights and thus attended school when they were older. ${ }^{20}$ The changes in the post-1925 data more accurately reflect ongoing changes in the demand for college among Americans.

In the post-World War II era college became considerably more accessible to and desired by Americans from most walks of life. The enrollment of men in college soared in the 1950 s and they outnumbered women about two to one, as can be seen in Figure 6. With the decline in the

\footnotetext{
20 In 1940, for example, only 14.7 percent of white men 30 to 34 years old had attended college. But by 1970 , when this cohort was 60 to 64 years old, the figure was more like 20 percent.
} 
age at first marriage for all Americans, college became, de facto, an active marriage market in which the supply of husbands greatly outstripped the demand. Women eventually increased their numbers in college, but during the period of the 1950 s and early 1960 s we must question whether the direct pecuniary returns to a college education justified their attendance. The direct pecuniary returns for the median female graduate probably fell short of the alternative rate of return. But the indirect pecuniary returns through the marriage market could have more than made up for the short-fall and may have been the initial impetus for the subsequent increase in the college attendance of women.

One can compute a simple, back-of-the-envelope calculation of the returns to women's college education under a number of reasonable assumptions. The median female college graduate in the mid-1950s married in her year of graduation and, if she married, she worked for 4 years and then exited the labor force for about 8 years. ${ }^{21}$ She reentered the labor force, therefore, at about age 35. A high school graduate, it will be assumed, also exited from the labor force after 4 years but remained out for 10 years or two more than the college graduate. The ratio of the earnings of a college graduate woman to those of a high school graduate was about 1.3 when the college woman entered the labor market and increased to about 1.4 by mid-life for both of them. ${ }^{22}$ In nominal amounts the college woman at the moment of her graduation in

\footnotetext{
${ }^{21}$ In a sample of about 700 female graduates of the class of 1957, to be discussed in the text, the majority married before or in their year of graduation. Of those who were married by 1964, or seven years after graduation, the median woman worked untll 1961 or for four years after graduation. In 1964 the median graduate had one 3 year old and an infant (or was probably expecting one). Among those without children more than 80 percent were in the labor force. The addition of a child under 3 years old reduced participation to 26 percent and a 3 to 5 year old reduced it to 35 percent. There were too few women with 6 year olds and over to observe when women, in this sample, began to reenter the labor market. I assume here that most reentered when their children began first grade. Thus they exited after 4 years and remained out for 8 years, or long enough for the youngest of the two to be 5 to 6 years old. My sense is that, for various reasons, this is an underestimate of the median time spent out and will, therefore, result in too high a rate of return.

22 The annual starting income for college graduates in the class of 1957 was about $\$ 3800$ (1957 dollars). This is very close to the figure from the 1960 PUMS for college graduate women, given an annual increase of about 2.5 percent. The ratio of a college to a high school graduate's annual income was 1.3, in the 1960 PUMS, for 25 to 29 year olds, but 1.4 for 44 to 49 year olds.
} 
about 1960 earned around $\$ 4000$ and the high school graduate of 1956 earned around $\$ 3000$. The direct expenses for each of the four years of college was $\$ 837$ for public universities and $\$ 1552$ for private universities. ${ }^{23}$ Both the high school and college graduate women are assumed to work continuously after they reenter the work force until age 60 , and their reentry earnings are taken to be those at the time of exit. ${ }^{24}$ Under these assumptions the rate of return to the four years of college investment was between 4 and 6 percent. ${ }^{25}$ The rate of return to college for men at that time exceeded 10 percent or more than double the rate for women. ${ }^{26}$ Even though the return to college for men and women -. given by the ratio of wages earned by a college graduate to those of a high school graduate - was comparable, the internal rate of return for women was half that for men because of briefer employment.

But this simple calculation does not consider that college affected a woman's future resources through the man she married, what I will term the "indirect" return to college. In 1960 the probability a woman 30 to 39 years old had married a college graduate was vastly increased by her graduating from college. Almost two-thirds of all college-graduate women, who were

${ }^{23}$ Tuition, room, and board for public and private universities in 1960 was:

$\begin{array}{lll} & \text { Public } & \text { Private } \\ \text { Tuition } & 241 & 853 \\ \text { Room } & 174 & 220 \\ \text { Board (7 day) } & 422 & 479 \\ \text { Total } & 837 & 1552\end{array}$

Source: U.S. Department of Health Education and Welfare, Office of Education (1960).

24 One can also build in some degree of human capital depreciation.

${ }^{25}$ The calculation is simply solving for $r$ in the standard equation: $\Sigma C_{N} /(1+r)^{t}+\Sigma Y^{t} /(1+r)^{t}=\Sigma \gamma^{\text {ths }} /(1+r)^{t}$.

where $C=$ direct costs of college, $Y^{C}=$ income of a college educated woman, $\gamma^{\text {th }}=$ income of a high-school educated woman. A woman is assumed to graduate from high school at age 18, work until she exits from the labor force at age 22 (presumably to raise a family), reenter the labor force at age 32, and retire at age 60 . If she, instead, graduates from college, she works from 22 to 26, exits at 26, reenters at 34, and retires at 60 . Wages for both high school and college graduate women rise with job experience so that the ratio begins at 1.3 but rises to 1.4 by midlife.

\footnotetext{
${ }^{28}$ See Freeman (1977).
} 
between 30 and 39 years and married, had a college graduate husband and more than a third of those who attended college, but did not graduate from a four-year school, had. Only 10 percent of the high school graduate women married a college graduate. Because so many more men than women attended and graduated from college in the late 1940s and 1950s, the data for the husbands are quite different. Husbands who graduated college stood about an equal chance of marrying a high school graduate, a woman who had attended college but did not graduate, or a woman who had graduated college. For the group of women 50 to 59 years old in 1960 , college did not increase the probabillty of marnying a college man as much as it did for the younger group - 47.5 percent as opposed to 63.7 percent college graduate women married a college graduate man. The matrices showing "who married whom" in Table 3 suggest, again, that college was far more of a marriage market in the 1950 s than it had been in the 1920 s or 1930s. Women who were 50 to 59 years in 1960 were 30 to 39 years in 1940, and the data for them in 1940 (also in Table 3) indicate somewhat more of a marriage market existed - 54.3 percent of women who graduated from college married men who did. But it should be remembered that less than 70 percent of the 30 to 39 year-old college graduate women had married by 1940 while 85 percent of women in the 30 to 39 year-old age group in 1960 had. Later marriages involved less positive assortative mating by education and also divorce was somewhat more important for the higher educated.

Not only did college-educated women stand a much higher probabllity of marying a college man, they also married men with higher incomes within each educational level, it will be seen. Further, among the women who attended college and married college men, those who married during college or immediately following graduation bought into husbands with higher earnings. That is, the early birds got the bigger worms. On the negative side, however, was that college women still had a somewhat lower probability of ever getting married, although it was considerably higher than for the previous cohort studied. For women 30 to 39 years old in 1960 , 6 percent of those who graduated high school but did not attend college had never married. Of 
those who attended college, but did not complete four years, 7.1 percent had not married. Of those who graduated college 15.1 percent were still in the never-married group in 1960, although by the 1980 s only 8 percent of this group had never married.

Both portions of the return to college - the direct or income enhancement effect and the indirect or marriage market component -- are likely to be overstated because the college educated tend to be more capable and better connected. In terms of the direct return, however, that for women is probably a better estimate of the true effect of college than that for men because much of it owes to a college woman's greater probability of being a teacher and being employed in the public sector. ${ }^{27}$ Women without a college diploma would have been excluded from many of these positions independent of their inherent abilities.

Estimating the indirect return raises the issue of whom a college woman would have married had she not attended college. To do so would require information on a woman's background to understand how women who went to college differed, prior to their college experiences, from those who did not. Although the assumptions employed here might overstate the returns to college through marriage, they probably do not for a large segment of the collegeeducated population who had quite ordinary backgrounds. The appropriateness of the indirect return estimate can also be bolstered in another manner. Not only did college women have a higher probability of marrying college men and not only did they marry the better incomegenerators among them, but those who married earlier in or after college married the better providers.

College, in the late 1940 s and 1950 s, became a very active marriage market, in addition to its being an arena for training young minds from various segments of American society. The "between" effect might be biased -- the better able self-select and would succeed even in the absence of the treatment - but the "within" and "early bird" effects should not be biased in the

${ }^{27}$ About 75 percent of the return to women's college education in the 1940 and 1960 PUMS was due to their employment in the public sector. 
usual manner.

The Indirect computation is quite simple and uses the 1960 PUMS; a complementary analysis is performed with a similar extract from the 1940 PUMS. ${ }^{28}$ Two age groups are analyzed that correspond as closely as possible to the first and second cohorts: women 30 to 39 years and women 50 to 59 years. ${ }^{20}$ The estimate yields what might be termed the "Mrs." effect to add to the original, direct estimate of the returns to college to produce a total return to college, including the direct and indirect pecuniary retums.

To compute the indirect retum to college a standard log earnings equation has been estimated for the husbands, to which are added variables concerning wife's education and the timing of their marriage in relation to her education (see Table 4). The findings will point to three aspects of the indirect return to the wife's education mentioned previously: (1) the enhanced probability of marying a more educated man; (2) marrying the better income-producer within an educational group; and (3) marrying the higher earner among all college educated men when one marries in college or in the year of graduation, that is the "early bird" effect. These effects, it will be seen, were stronger for the cohort born from 1921 to 1930 and graduating from 1943 to 1952 than for a cohort somewhat intermediate between the first and the second, born from 1901 to 1910 and graduating from 1923 to $1932 .^{30}$

The experiment performed in Table 5 Involves taking a high school graduate woman in the 1950s, giving her four years of college, and then observing her husband's income in 1960

\footnotetext{
${ }^{28}$ All white women were selected from the 1/1000 1960 PUMS and husband's information was recorded for those who were currently married. The 1960 PUMS contains information on wage and salary income as well as that from self-employment. The 1940 PUMS does not contaln information on self-employment income and is, therefore, somewhat less useful in a study of the college educated. In 1940 only sample-line women and their husbands can be used because only sample-line individuals (one in each household) answered questions on the age at first marriage and parity. Because of the reduction in sample size, the $1 / 100$ PUMS is used for 1940. The 1950 PUMS cannot be used for this study because only the sample-line individual from each household was seiected.
}

29 The $\mathbf{5 0}$ to $\mathbf{5 9}$ year old group is somewhat younger than the first cohort.

${ }^{30}$ The cohort and graduation years assume that a woman graduates at 22 years. 
when she was between 30 and 39 years. The total impact is to increase her husband's income by almost 40 percent. $^{31}$ The largest component (66.5 percent) comes from altering the probability she will marry a man at each level of his education, as given in Table 3 (see 1960 data). The likelihood that she will marry a man who attended or graduated from college increases while the likelihood that she will marry at all other levels decreases. This change, then, increases a husband's income by 27 percent.

But increasing her education results in another effect apparent in the coefficients on wife's education in the husband's earnings equation. Within husband's educational levels the college graduate woman married the higher income-earning man. This factor accounts for 22.5 percent of the total or a 9 percent gain in husband's income for the college graduate woman over that of the high school graduate. Because almost 80 percent of all college graduate women married a man who attended some college, the effect can be thought of as part of the gains from the college marriage market. Another possible interpretation is that women with more education are better able to assist their husbands and thereby directly enhance their income. Because the factor is not of importance for the 50 to 59 year old group (see Table 4), the marriage market hypothesis seems more compelling. ${ }^{32}$ Finally, a third effect involves the fact that marrying early, either in college or upon graduation, also increases one's earnings - notice the coefficient of 0.0757 on "married in college." The "early bird" effect adds the remaining 11 percent of the

\footnotetext{
${ }^{31}$ The total change in (the log of) income from Table 5 is 0.334 and exp $(0.334)=1.3965$ or about 40 percent. The total change of 0.334 is almost identical to the difference in the coefficients on wife's education (college minus high school graduate $=0.324$ ) in a regression on their husband's income, not including any other covariates.

32 The effect, however, is important for the 30 to 39 year old group in 1940, who become the 50 to 59 year old group in 1960 . One possible problem is that the composition of the group changes as women who were married in 1940 divorce and those who were not married in 1940 become married for the first time after. By restricting the estimation in 1960 to those who married before age 40 , one can hold constant at least some of these factors the change the composition of the sample. The results are still not significant in 1960 suggesting that the within effect may decline over time. Another possibility is that the 50 to 59 year old group in 1960 is anomalous for some other reason. The same age group in 1940 does reveal a within effect comparable in magnitude to that in 1960.
} 
total or about a 4 percent gain in income for the college graduate woman. ${ }^{33}$

Overall, therefore, the experiment of giving a high school graduate woman a college education in the 1950 s increases her income through the marriage market by 40 percent. How one treats this income depends on various assumptions concerning, how long she remains married and whether, should she divorce, she receives alimony in proportion to her husband's income. It also depends on whether we treat the gain to be full or whether we split it between the parties. A further justification for including the entire amount is to consider the objective of those who invest in her education - her parents. If they value the well-being of their grandchildren, they would consider the entire increment in income that their grandchildren would receive if their daughter went to college. Thus, they would value both the direct returns in terms of their daughter's income and the indirect returns in terms of her husband's income.

The indirect return from husband's income would be somewhat less if ex post divorce rates for this cohort were considered. But the cohorts marning in the 1950 s could not have known these rates and wouid have considered the ex ante divorce rates for previous cohorts. These were substantially lower than thelrs was to be and occurred only after many years of marriage (Preston and McDonald 1979). Because the period to divorce decreased with successive cohorts, the indirect return calculation is probably inapplicable for them. That is, subsequent generations divorced earlier into their marriages and had better information from previous cohorts about their probabilities of divorce.

Following the logic of treating the indirect gain as we do the direct gains from education and assuming the woman marries and does not divorce, the total returns to her education are now greatly augmented and, under reasonable assumptions, double. The total return to college for the second cohort, rather than being in the range of 4 to 6 percent, is now closer to 10 or 11 percent. Thus the full return to women's college education in the 1950 s is increased from a value

${ }^{33}$ The 4 percent figure is derived by multiplying the total effect of 0.0757 by the percentage of all married college graduate women (whose husbands are college men) who married before or during their year of graduation. 
that is somewhat less than the real return to assets at that time to one that is more in line with the returns to college education for men. Families, therefore, should have been willing to send a daughter to college if they viewed her marriage prospects as being enhanced by the experience. Thus it would not be surprising if many families refused to pay for their daughter's education if they thought she would simply marry the "boy next door."

In sum, women graduating in the 1950 s attended college at a time when the ratio of men to women undergraduates was at an all-time peak in the United States, and they married at the highest rate of any college group in the century. Not surprisingly, the vast majority met their mates in college and married before or soon after graduation. College was far more of a marriage market at that time than during any period before or after. Contemporary commentary lamented the fact that college women were not staying in school long enough to graduate and were marrying as soon as they could. ${ }^{34}$

Although the direct return to their college degree was not high, the direct and indirect returns were substantial enough to justify women's college education on purely pecuniary grounds. They bought into comfortable lives, but not necessarily ones that were always satisfying. We can peer further into their lives using a survey of the Women's Bureau of the Department of Labor that interviewed 7 percent of the women graduating in the class of 1957 and resurveyed them seven years later in 1964 (U.S. Department of Labor 1966). These surveys reveal much about their aspirations, their husbands' attitudes toward their working, their own work and fertility histories, and their treatment in the labor market of the late 1950 s and early 1960 s.

Of the almost 6,000 college graduate women surveyed in 1957 by the Women's Bureau, about 700 were retrieved from the National Archives and linked to the resurvey in 1964, to which

34 The data in Table A2 indicate that the college drop-out rate peaked during the second cohort. The drop-out rate is related to the ratio of the percentage in a cohort who graduated college to the percentage who attended college. The difference is also due to the percentage in two-year degre日-granting colleges and normal schools. A smaller fraction of women were in normal schools in the 1950 s than before and a smaller fraction were in two-year degree-granting colleges in the 1950s than later. For both these reasons, it seems reasonable that the actual drop-out rate was considerably higher in the 1950s than before or after. 
85 percent of the original women responded. The returns include, among other information, college major, work histories, earnings, ages of children, and husband's occupation. The first survey was taken in February 1958, or about eight months after most graduated, and even by then more than 40 percent had married. The survey did not ask husband's income, although it did ask the wage or salary of the respondent and both of their occupations. By using information on husband's occupation and income by occupation from the 1970 census, I compute an estimate of husband's income. Early blrds did get bigger worms, in this survey as well, and the husbands of these women earned about 8 percent more than did those who married after the first survey but before the second, taken in 1964 - a figure that is almost identical to the coefficient of 0.0757 in Table 4.35

An interesting feature of this sample is that it contains information on the wife's perception of her husband's chauvinism. Because, in this sample, the fathers of infants almost uniformly disapproved of their wife's working, I restrict the analysis to those couples without infants in 1964. One-half of the husbands in the group marrying early favored their wives working (among those having no infants in 1964), while three-quarters of those in the group marrying later did, that is 50 percent more. The woman who married earlier, and therefore the woman who probably married the guy she met in college, bought into a richer husband, a larger family, far more time as a housewife, more part-time work and less full-time work, less investment in her occupation, and a husband who was far less favorably disposed to her working for pay. The vast majority of the women in the class of 1957 responded to a question in the survey that they planned to work before marriage, exit from the labor force when they had children, and reenter in the future but not with the intention of having a career. When I termed their choice "family then job," it

${ }^{35}$ The independent variables in a log (husband's) earnings regression are just whether the couple married by the first survey in 1957, that is a mere eight months after graduation, and whether they reside in an urban area in 1964. Earnings are those that correspond to the husband's 1964 occupation from the 1970 census on a national basis. The estimation is restricted to women under 30 years old in 1964, thus those who probably went to college directly following high school. The coefficient on whether they were married in 1957 is 0.079 (t-statistic 2.41; number of observations $=514$ ). 
reflected their own plans and was not a subjective characterization of their intentions thirty-five years later.

The cohort I have been discussing - that graduating between 1940 and 1960 - includes a pivotal generation in the feminist movement. These were the women of Betty Friedan's The Feminine Mystique (1963) In which Friedan described the experiences of her own generation of women who graduated college in the 1940s. Feminism sprung from this generation, it has been said, because they knew that they were as able as their male friends in college, but when they left college they encountered a world that was not ready for them (see also J. Freeman 1975). Many of the comments in the 1957 and 1964 Women's Bureau surveys echo the voices in Friedan's work. "It is a source of great frustration to be unable to use one's education or training," sald one graduate. Many reported that In fields other than teaching, social work, and nursing, college women were required to have typing skills and little else. Surveys of personnel managers in the late 1950s concluded similarly: there were few jobs for college women except in teaching, nursing, and allied professions (see Goldin 1990, p. 176). In part the paucity of jobs for college women resulted because they had never been numerically important. But in large measure it was also because college women were taking long spells out from the labor market. They were having family and job serially, and devoting themselves to husband and children with the same time commitment as were women with less education.

To recap, the second cohort had substantially higher marriage and fertility rates than the first cohort, were in the labor force considerably more when older but not much more when younger, and were teachers to almost the same degree. Three major factors account for the change in the demographic and economic experiences of college women. Although I have emphasized many of the constraints that college women of the second generation faced, their lives were altered by the substantial decrease in barrlers to their employment during and after World War II. Before the 1940s the vast majority of school districts and many employers of office workers had "marriage bars" - stated policies that married women would not be hired and that 
single women would be fired upon marriage (see Goldin 1990, 1991). Added to the marriage bars were reinforcing and pervasive norms restricting the ability of married women to work for pay. Prior to the removal of the marriage bars, most college women faced a difficult choice: they could marry or they could get employment.

The second generation faced far fewer bars of this nature. Of additional importance is that the number of men entering college increased substantially in the 1940s and 1950 s and the initial increase preceded that in the college attendance and graduation of women. Finally, all Americans were marrying earlier and having more children, and these changes affected the college educated as well. The three changes were reinforcing. College women no longer had to treat marriage and employment as alternatives in life, and college was no longer just a place to learn for it was, de facto, transformed into a place to meet one's spouse. College opened doors to a restricted number of professions and enabled women to meet college men. Thus the returns to college for women were twofold. But as this generation aged it became less pleased with its small victories, and successive generatlons of college women launched a campaign for more equality and finally for true equality.

\section{The Third Cohort: Family and Career}

Jumping ahead another twenty years brings me to the third cohort - college women who graduated since 1980. We do not have measures of economic and demographic outcomes for them comparable to those for the previous cohorts, because this cohort is still too young to have completed much of its history.

We do know the following. Labor force participation rates ${ }_{i}$ even among those who are married, are more than twice those of the cohort just discussed. That is certainly not surprising since the labor force participation rates of all women have climbed. The difference in participation rates between those without college and those who graduated college has widened for the lower age groups and narrowed for the upper age groups. The proportion who are opting for the 
traditional profession of the college woman of the past - teaching - is about one-half the level of the preceding cohort (see Appendix Table A2). In terms of both employment and occupation, there is a narrowing gap between male and female college attendees and graduates. But the gap in terms of demographic outcomes, particularly for women with more than four years of college, may be widening.

The proportion never married among female college graduates 25 to 34 years old in 1988 was 30.7 percent, substantlally higher than for the preceding cohort (21.4 percent), although all Americans are marrying later now. ${ }^{36}$ College graduates are also moving back to the first cohort in terms of the percentage who have never had children. For those 25 to 34 years old in 1990 and who ever married, 40.6 percent had no children, and the difference between this figure and that for ever-married women without college is 23.9 percentage points - higher than for the cohort born around 1910 (see Table 1). But the fertility histories of the third cohort are still quite incomplete, and the percentage who plan to have children at some time in their lives is about 12 percent across all marital statuses and 5.8 percent among those currently married. ${ }^{37}$ These are, by extrapolation using the experiences of other cohorts, rather unattainable expectations.

Also like the first cohort, educated from 1900 to 1920 , the most recent one is taking an academically serious set of studies. Their college majors resemble those of the men in their graduating classes to a remarkable degree. I have said little about the content of education across the three cohorts. The first cohort entered college before students majored in particular subjects, and colleges for women aimed to give to them what other schools offered men. Some time in the 1920s, particularly with the realization that college women were not marrying at the same rate as their non-college counterparts, a movement began to offer college women courses

${ }^{36}$ Indeed, the figure for male college graduates in the same age group is 41.7 percent (U.S. Bureau of the Census 1991a).

${ }^{37}$ U.S. Bureau of the Census (1991). The percentage expecting no lifetime births refers to white women, 18 to 34 years old with $\geq 4$ years of college. It is, therefore, comparable to the 25 to 34 year old group In the same year. 
that would serve them at home and in their employments of choice. By the 1950s education, nursing, and home economics were among the dominant majors for women. The majors of the second cohort were vastly different from those of their male counterparts, and were probably more dissimilar than for any other cohort. In 1957, for example, 33 percent of women majored in education, 8 percent in English, 8 percent in home economics, and 6 percent in nursing. Thus fully 55 percent were in fields in which very few men obtained degrees. By the graduating class of 1990, however, men's and women's majors were more similar than anytime since the inception of the major concept. One quarter of all graduates majored in business and management, and women were 47 percent of the majors in this field. Only 28 percent of women majored in the four more traditionally female majors listed above (U.S. Department of Education 1991).

\section{Summary and Conclusions}

Two related issues have been addressed in this paper - why women went to college across the past century and how college affected their lives. College-educated women today have employment and occupational outcomes more like those of comparably-educated men than do women with lower levels of education. It seems clear why women today, like men, invest in higher education. But this study has revealed that this was not always the case.

Around the turn of this century a rather small fraction of men and women attended and graduated from college. The fraction for men climbed considerably after World War II, although it began to increase for women at about the same time. Although college men outnumbered women by about 2 to 1 in the early 1950s, there is now virtual parity in their numbers. Why women's college attendance rose after World War II is relevant to both questions posed here.

Sometime during the 1940 s women realized that they could have family and job - albeit serially timed, and that college could enable and enhance both. Although the direct returns to college for women probably did not justify their increased enrollments, the heightened indirect returns through the marriage market probably did. Thus some portion of the increase in college 
attendance and graduation rates of women in the post-World War II era was due to the simple fact that women followed men Into college. But sometime after women exited college they set in motion a process that led to an increase in the direct returns to college, primarily through their more extensive life-cycle labor force participation and their more remunerative occupations. This brings me to the second issue -- how did college affect the lives of American women?

All cohorts of college-educated women have had a decreased probability of marriage and fewer children ever-born than lesser-educated women. The differences in these life-course events were greatest for the first cohort considered, after which they narrowed considerably with the second cohort before widening again for the most recent cohorts. Life-cycle 'employment conditional on marital status, however, increased secularly across all cohorts of college women. College did open certain doors - to teaching, for example. But the constraints in the labor market facing most generations of coilege women - such as marriage bars in teaching - were overwhelming. College women, possibly because they were few in number, had little chance to effect change on a larger scale until the 1950s. Ironically, perhaps, a process of more profound social change was set in motion with the second cohort of college women who, by and large, entered college with the least motivation for academically serious studies and whose "Mrs." degrees were worth nearly half of the total returns from their B.A.s.

In developing countries today, the education of women has an extremely high return through better infant and child health, sharply lessened infant mortality, and decreased fertility. The returns to post-primary school education of women are different but no less grand. In the United States it was the rise of high school education that initially changed work, labor force participation, and earnings for the vast majority of women. It was college education that led to the more or less complete integration of women into the economy and society, a transformation that occurred over the course of a century. 
Figure 1

Percentage of White Males and Females Attending College, by Birth Cohort

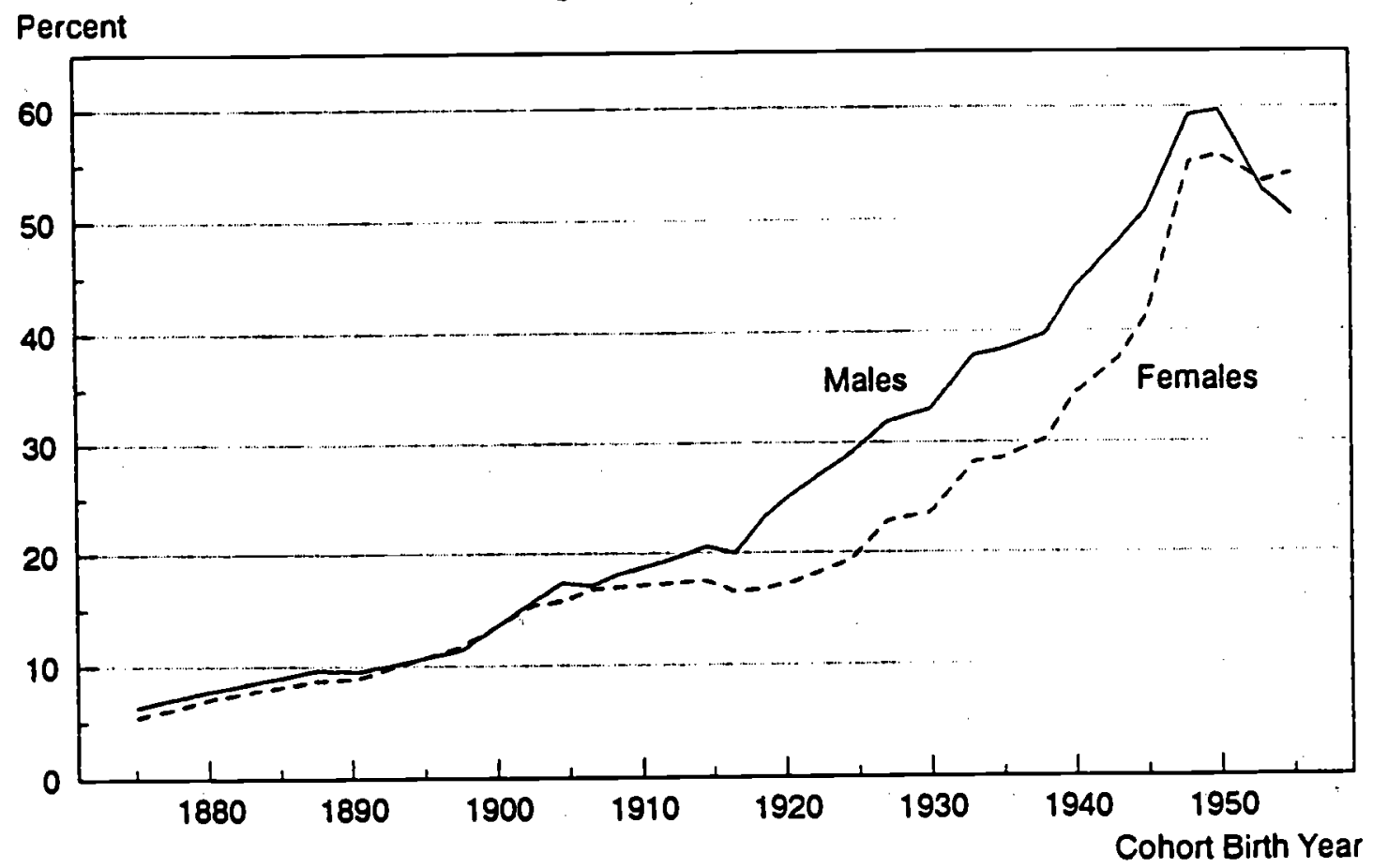

Sources: U.S. Bureau of the Census, Current Population Reports, P-20 series, "Educational Attainment in the United States," various dates. See also Appendix Table A1.

Notes: In virtually all cases only the responses of individuals 45 to 54 or 55 to 64 years old were used. For cohorts born since 1945 projections were made to 1995 or 1997 on the basis of changes for the preceding cohort that was 35-39 (30-34) years in 1977 and $45-49(40-44)$ years in 1987. 
Figure 2

Percentage of White Males and Females

Graduating from College, by Birth Cohort

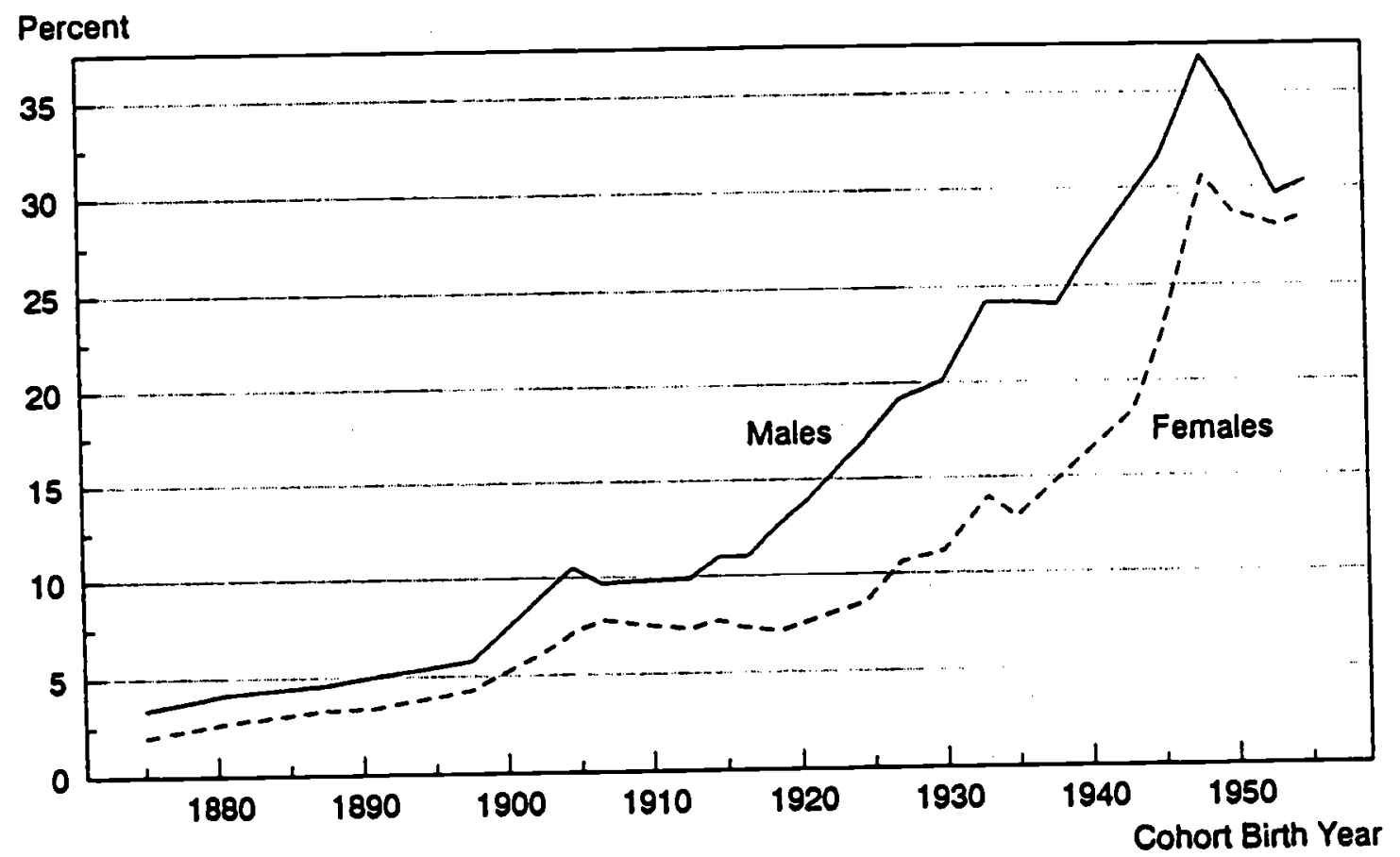

Sources: U.S. Bureau of the Census, Current Population Reports, P.20 series, "Educational Attainment in the United States," various dates. See also Appendix Table A1.

Notes: In virtually all cases only the responses of individuals 45 to 54 or 55 to 64 years old were used. For cohorts born since 1945 projections were made to 1995 or 1997 on the basis of changes for the preceding cohor that was 35-39 (30-34) years in 1977 and $45-49(40-44)$ years in 1987. 
Figure 3

Percentage of White Women

$\%$ with No Births by Age $35-44$

with No Births by Age 35-44

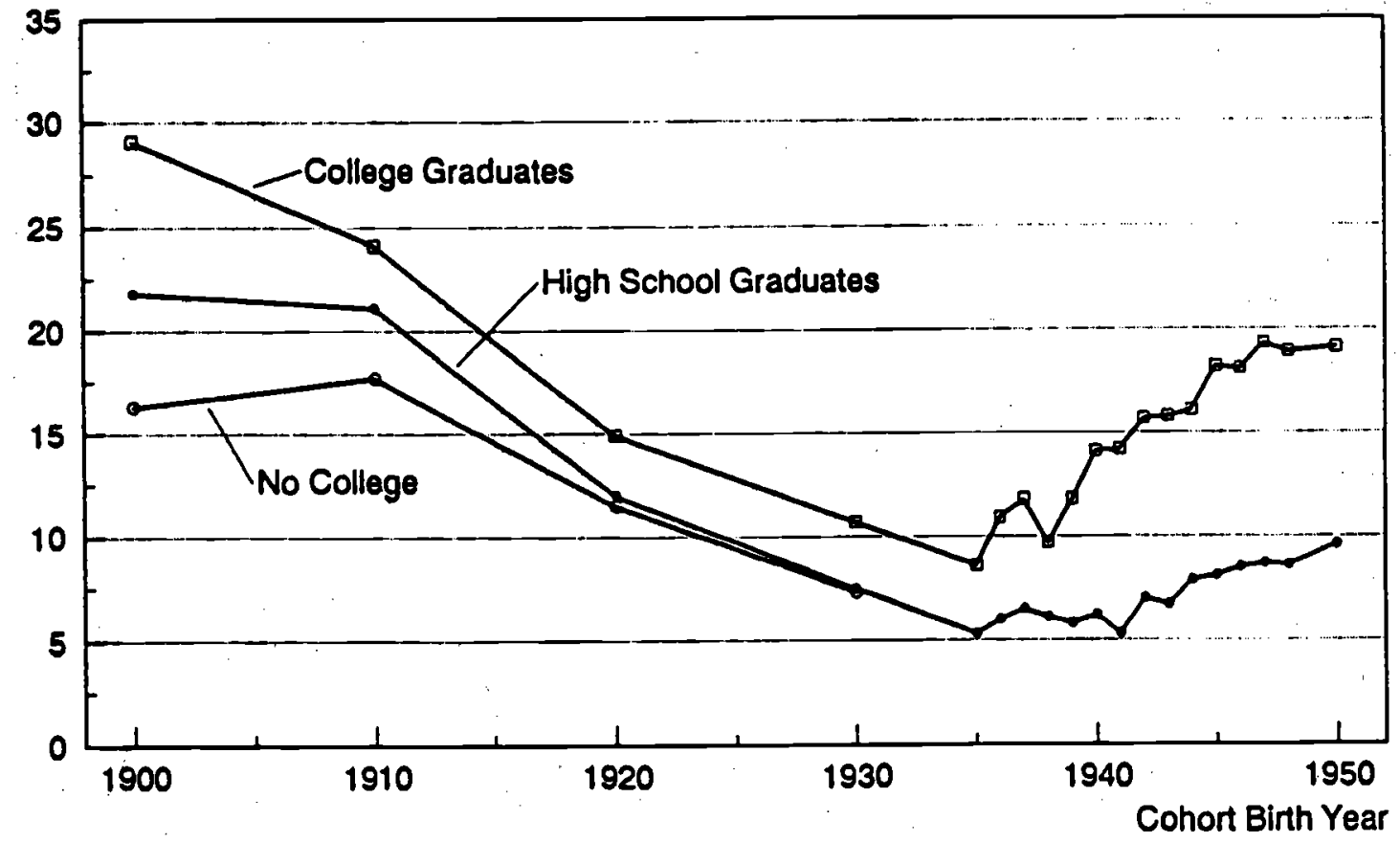

Sources: 1940: Table A2; 1950-1970: U.S. Bureau of the Census (1955, 1964, 1973); post-1970: U.S. Bureau of the Census, Curremt Population Reports, P.20 series, "Fertility of American Women," various dates.

Notes: All data are for white women only. The 1960 data in Table A2 are derived from the 1960 PUMS while the data in the figure are from the published census returns. The differences are slight. 
Figure 4

Percentage Never Married, College Graduate White Women

\% Never Married

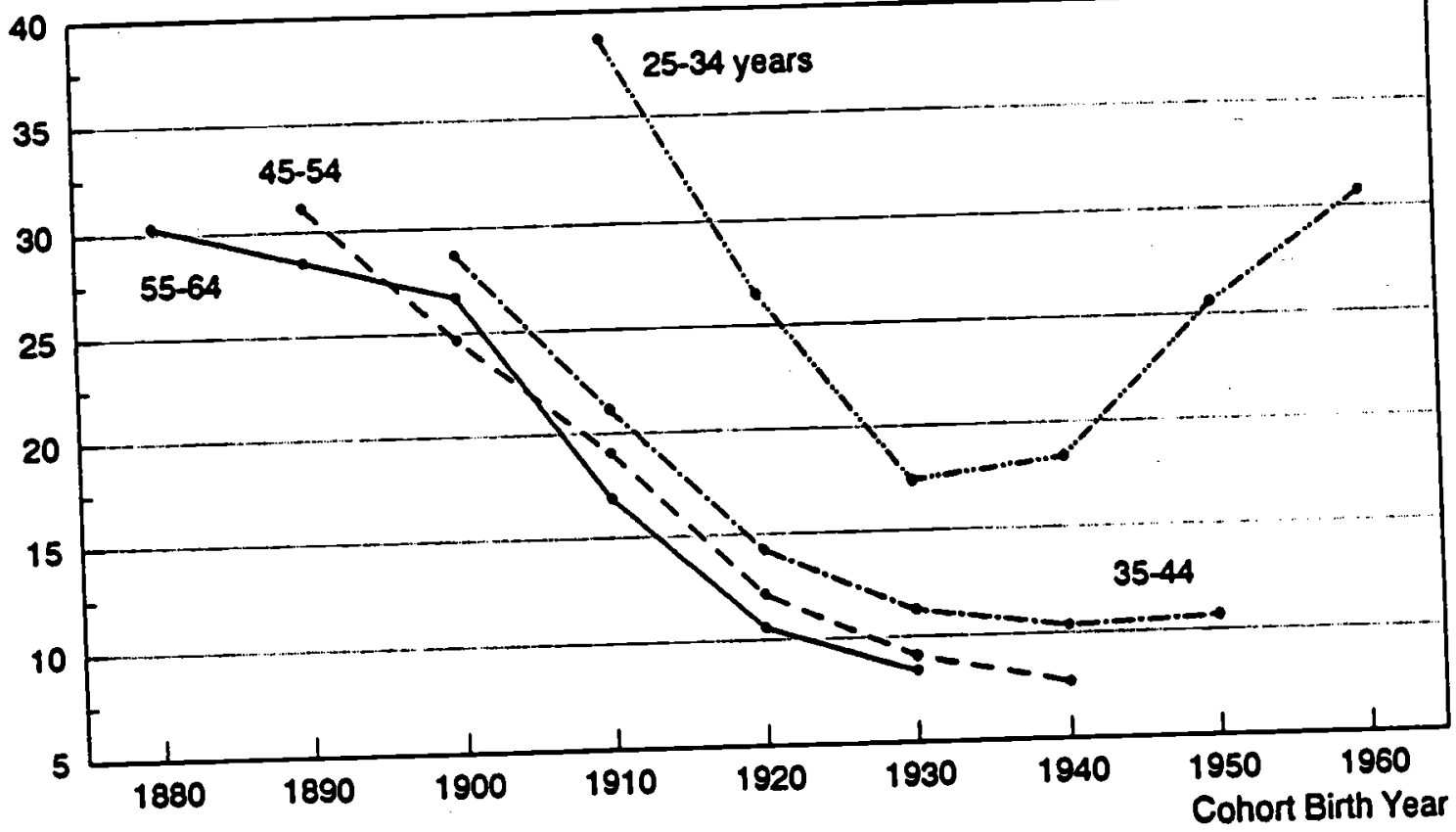

Sources: U.S. Bureau of the Census $(1953,1966,1972,1985)$ and Table 1 for 1940 and 1988/90.

Notes: The published data for 1960 have been used instead of the data from the 1960 PUMS given in Table 1. The differences between the two sets of numbers are slight. I do not know why the 55-64 year old figure for the cohort born in 1900 is greater than that for those 45-54 years old. The same reversal appears in the data for those having no college. 
Figure 5

Percentage Never Married, White Women with No College

\% Never Married

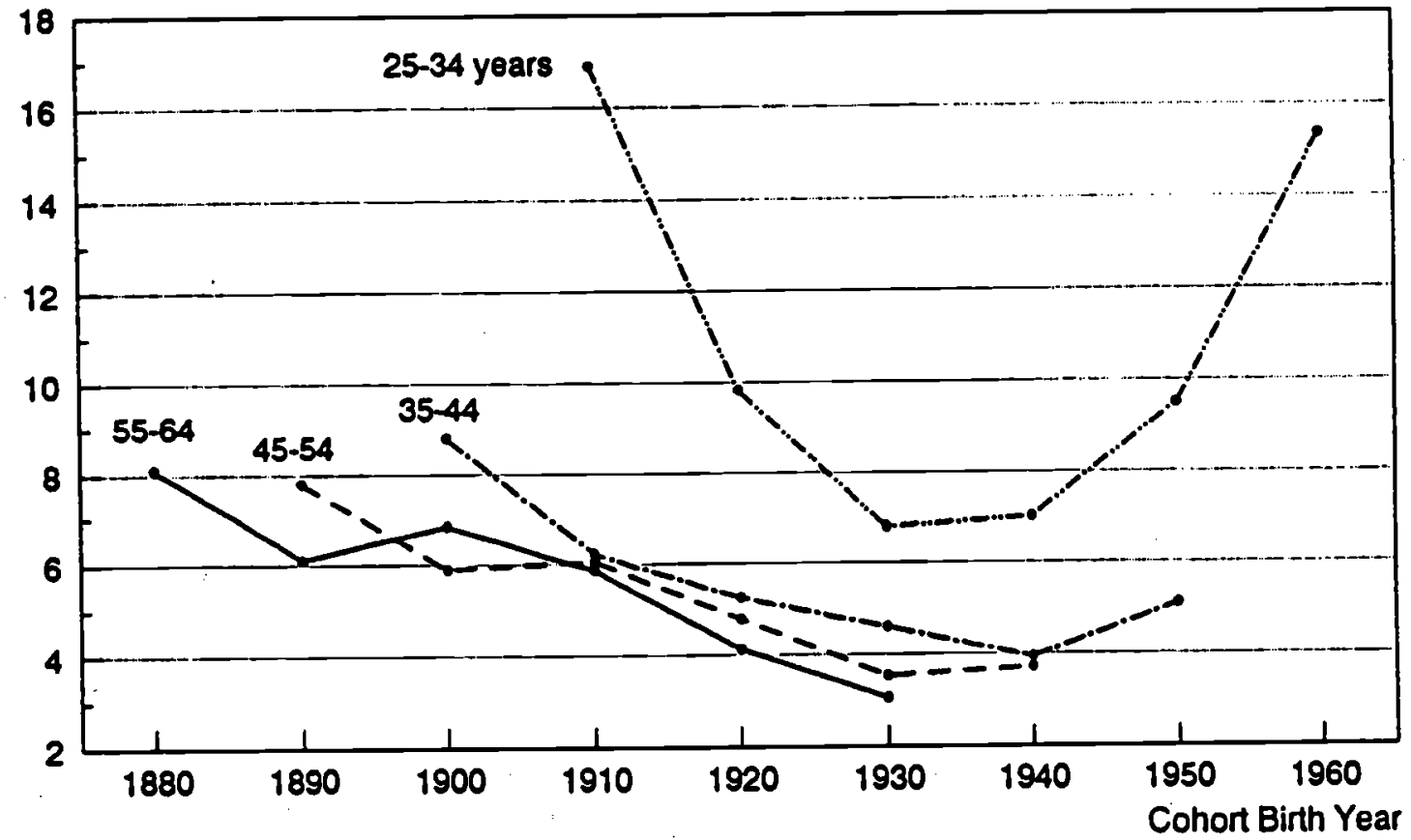

Sources: U.S. Bureau of the Census (1953, 1966, 1972, 1985) and Table 1 for 1940 and 1988/90.

Notes: The published data for 1960 have been used instead of the data from the 1960 PUMS given in Table 1. The differences between the two sets of numbers are slight. I do not know why the 55-64 year old figure for the cohort born in 1900 is greater than that for those 45-54 years old. The same reversal appears in the data for those attending college. 
Figure 6

Ratio of Male to Female Undergraduates

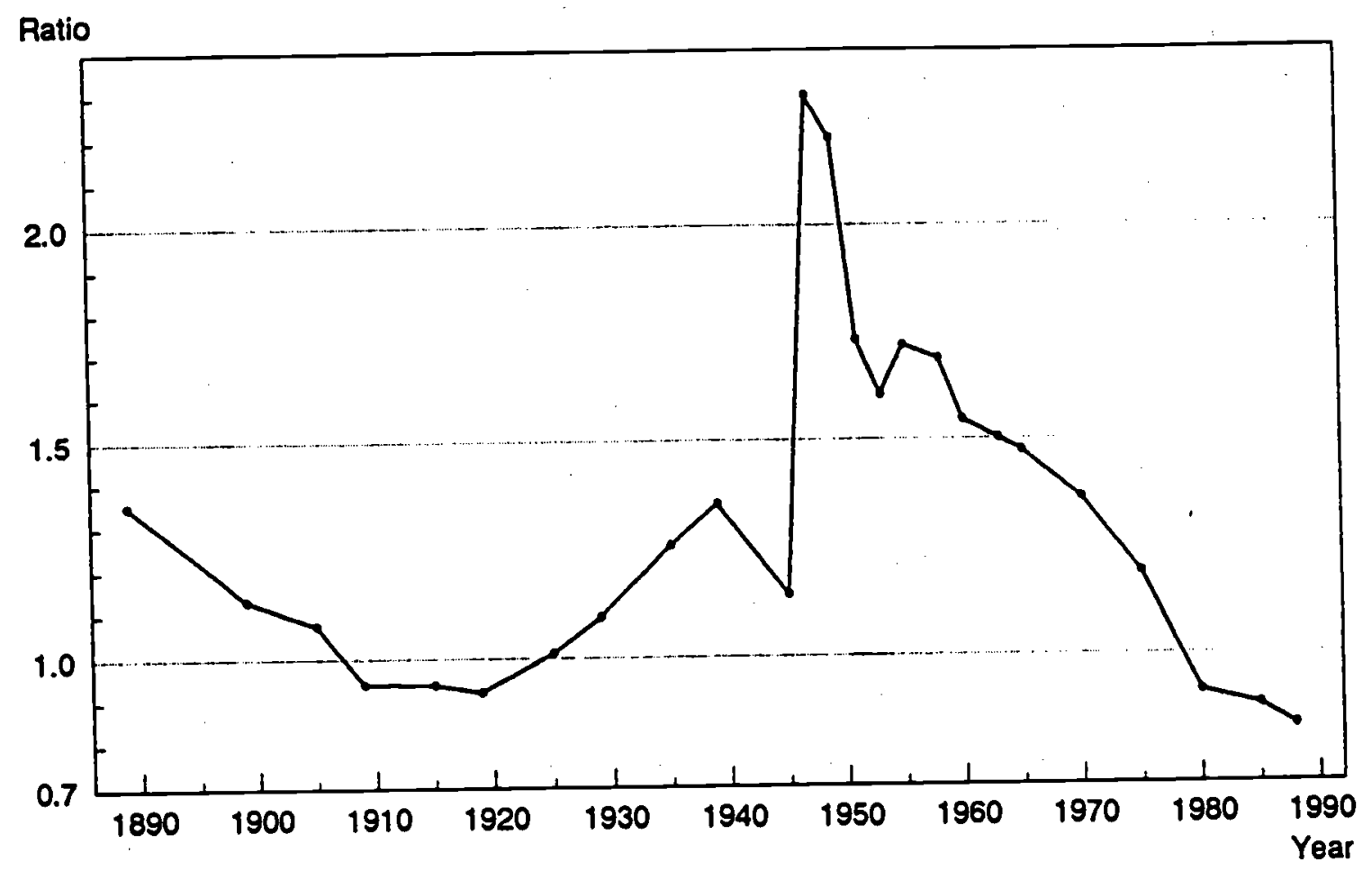

Sources: 1889 to 1953: Bureau of Education or Office of Education or U.S. Department of Health, Education and Welfare, Biennial Survev of Education. 1960 to 1965: U.S. Department of Health, Education, and Welfare, Opening (Fall) Enrollment in Higher Education. 1970 to 1988: U.S. Deparment of Health, Education, and Welfare, Digest of Education Statistics.

Notes: Undergraduate enrollments Include colleges, universities, junior colleges or two-year colleges, normal schools, and teachers' colleges. They do not include summer sessions. Parttime and full-time students are treated equally, and some of the rise of female attendance in the most recent period is due to the large enrollment of women who attend college on a part-time basis. Enrollment in graduate school and for professional degrees has been subtracted. Various assumptions have been employed and interpolations used in several years. All undertying data are available upon request from the author. 


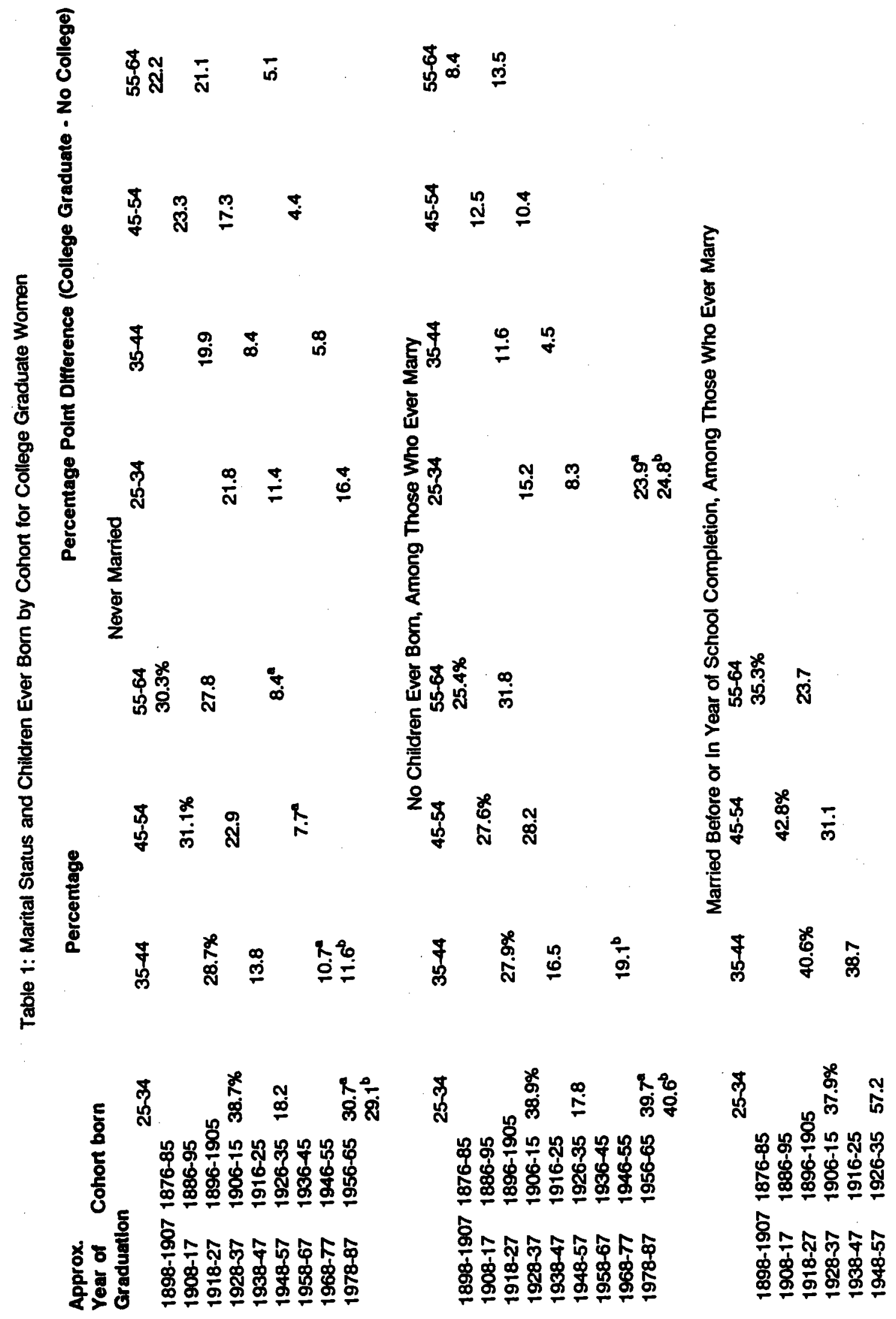




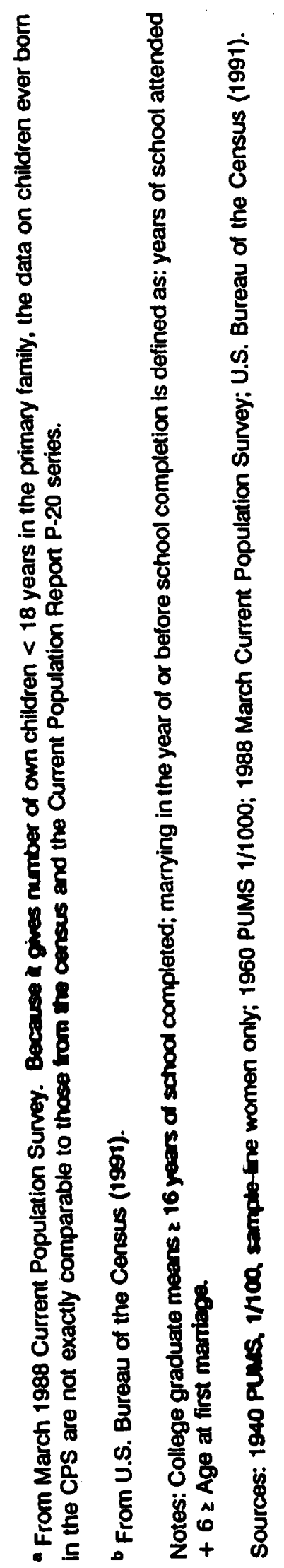




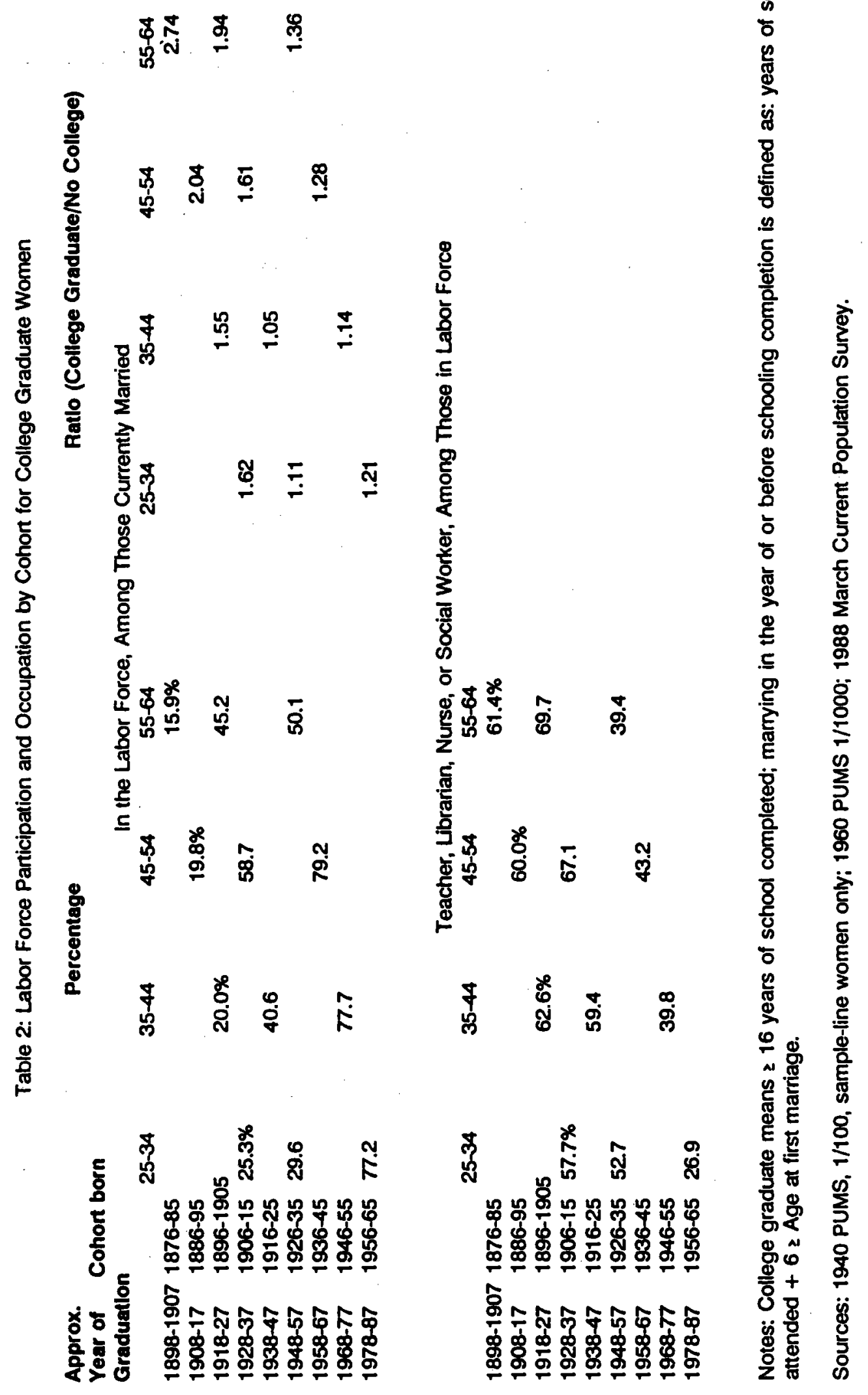


Table 3: Who Marries Whom by Education of Wife and Husband, 1960 and 1940 1960

Wives, 30 to 39 Years

Percentage of Wives, by Years of Schooling, Marrying Men in Each Schooling Group

Wife's Years of Schooling

$0-7$

8

9-11

12

$13-15$

$\geq 16$

\begin{tabular}{rrrrrrr}
\multicolumn{8}{c}{ Husband's Years of Schooling } \\
$0-7$ & \multicolumn{1}{c}{8} & $9-11$ & 12 & $13-15$ & $\geq 16$ & Total \\
57.9 & 14.6 & 16.8 & 7.7 & 2.0 & 1.0 & $100 \%$ \\
22.5 & 31.3 & 25.2 & 17.1 & 2.8 & 1.1 & $100 \%$ \\
13.2 & 19.0 & 33.6 & 25.8 & 6.3 & 2.2 & $100 \%$ \\
7.9 & 8.3 & 21.0 & 42.1 & 13.0 & 10.6 & $100 \%$ \\
1.6 & 3.3 & 8.6 & 24.9 & 25.7 & 35.9 & $100 \%$ \\
2.0 & 1.7 & 4.6 & 12.9 & 15.1 & 63.7 & $100 \%$
\end{tabular}

Percentage of Husbands, by Years of Schooling, Marrying Women in Each Schooling Group

Wife's Years

of Schooling

$0-7$

8

9-11

12

$13-15$

$\geq 16$

Total
Husband's Years of Schooling

$\begin{array}{crrrrr}0.7 & 8 & 9-11 & 12 & 13-15 & \geq 16 \\ 36.3 & 8.7 & 5.7 & 1.8 & 1.2 & 1.0 \\ 17.6 & 23.3 & 10.7 & 5.1 & 2.2 & 1.0 \\ 24.2 & 33.0 & 33.2 & 18.0 & 11.5 & 3.3 \\ 19.2 & 30.9 & 44.3 & 62.6 & 50.5 & 33.8 \\ 1.6 & 3.0 & 4.6 & 9.4 & 25.2 & 29.0 \\ 1.3 & 1.0 & 1.6 & 3.1 & 9.4 & 32.8 \\ 100.0 \% & 100.0 \% 100.0 \% & 100.0 \% 100.0 \% & 100.0 \% \\ \text { Wives, } 50 \text { to } 59 \text { Years }\end{array}$

Percentage of Wives, by Years of Schooling, Marying Men in Each Schooling Group
Husband's Years of Schooling

\begin{tabular}{rrrrrr}
$0-7$ & \multicolumn{1}{c}{8} & $9-11$ & 12 & $13-15$ & $\geq 16$ \\
70.5 & 17.5 & 8.3 & 2.7 & 0.7 & 0.4 \\
25.7 & 44.3 & 17.4 & 8.7 & 2.7 & 1.3 \\
19.0 & 25.2 & 34.8 & 12.1 & 5.2 & 3.7 \\
8.3 & 19.9 & 18.3 & 32.7 & 11.0 & 9.8 \\
7.5 & 12.2 & 15.8 & 19.4 & 22.7 & 22.4 \\
2.5 & 9.3 & 10.4 & 16.1 & 14.3 & 47.5
\end{tabular}

Percentage of Husbands, by Years of Schooling, Marrying Women in Each Schooling Group

Wife's Years

of Schooling

$0-7$
8
$9-11$
12
$13-15$
$\geq 16$

Husband's Years of Schooling

\begin{tabular}{rrrrrr}
$0-7$ & \multicolumn{1}{c}{8} & $9-11$ & 12 & $13-15$ & $\geq 16$ \\
53.1 & 14.1 & 9.1 & 3.7 & 1.9 & 1.0 \\
23.7 & 43.6 & 23.2 & 14.6 & 9.1 & 3.9 \\
13.3 & 18.9 & 35.3 & 15.6 & 13.5 & 8.6 \\
6.3 & 16.2 & 20.3 & 45.8 & 31.1 & 24.8 \\
3.0 & 5.2 & 9.1 & 14.1 & 33.3 & 29.2 \\
0.5 & 2.1 & 3.1 & 6.2 & 11.0 & 32.6
\end{tabular}


Percentage of Wives, by Years of Schooling, Marrylng Men in Each Schooling Group

Wife's Years

of Schooling

0-7

8

9-11

12

13-15

$\geq 16$

\begin{tabular}{rrrrrr}
\multicolumn{8}{c}{ Husband's Years of Schooling } \\
$0-7$ & \multicolumn{1}{c}{8} & $9-11$ & 12 & $13-15$ & $\geq 16$ \\
67.8 & 20.0 & 8.1 & 2.9 & 0.7 & 0.5 \\
22.4 & 53.9 & 14.4 & 6.0 & 2.1 & 1.2 \\
15.7 & 28.5 & 35.5 & 12.5 & 5.4 & 2.5 \\
6.5 & 19.5 & 19.8 & 33.3 & 10.4 & 10.5 \\
4.4 & 13.9 & 14.5 & 20.9 & 22.5 & 24.0 \\
3.5 & 5.8 & 8.4 & 12.5 & 15.6 & 54.3
\end{tabular}

Percentage of Husbands, by Years of Schooling, Marrying Women in Each Schooling Group

Wife's Years

of Schooling

$0-7$

8

9-11

12

$13-15$

$\geq 16$
Husband's Years of Schooling

\begin{tabular}{rrrrrr}
$0-7$ & \multicolumn{1}{c}{8} & $9-11$ & 12 & $13-15$ & $\geq 16$ \\
55.0 & 13.5 & 8.7 & 4.1 & 2.2 & 1.4 \\
23.8 & 47.5 & 20.2 & 11.1 & 8.4 & 4.3 \\
13.5 & 20.4 & 40.3 & 18.8 & 17.2 & 6.9 \\
5.6 & 13.9 & 22.5 & 79.9 & 33.4 & 29.2 \\
1.5 & 3.9 & 6.3 & 12.1 & 28.0 & 25.8 \\
0.6 & 0.9 & 2.1 & 4.0 & 10.8 & 32.5
\end{tabular}

Wives, 50 to 59 Years

Percentage of Wives, by Years of Schooling, Marrying Men in Each Schooling Group

Wife's Years

of Schooling

$$
0-7
$$

8

9-11

12

$13-15$

$\geq 16$

\begin{tabular}{rrrrrr}
\multicolumn{8}{c}{ Husband's Years of Schooling } \\
0.7 & \multicolumn{1}{c}{8} & $9-11$ & 12 & $13-15$ & $\geq 16$ \\
77.5 & 17.2 & 3.2 & 1.4 & 0.7 & 0.4 \\
20.5 & 62.6 & 8.3 & 4.9 & 2.1 & 1.5 \\
18.0 & 30.1 & 31.5 & 11.4 & 5.7 & 3.3 \\
8.0 & 21.2 & 12.9 & 34.6 & 10.2 & 13.1 \\
7.8 & 20.3 & 15.0 & 14.3 & 20.1 & 22.6 \\
7.7 & 8.3 & 9.6 & 13.5 & 11.4 & 49.6
\end{tabular}

Percentage of Husbands, by Years of Schooling, Marrying Women in Each Schooling Group

Wife's Years

of Schooling

$0-7$
8
$9-11$
12
$13-15$
$\geq 16$

Husband's Years of Schooling

\begin{tabular}{rrrrrr}
0.7 & \multicolumn{1}{c}{8} & $9-11$ & 12 & $13-15$ & $\geq 16$ \\
70.1 & 16.3 & 10.3 & 5.6 & 6.1 & 2.8 \\
19.6 & 62.7 & 28.1 & 20.0 & 18.6 & 11.1 \\
6.9 & 11.0 & 38.8 & 16.9 & 18.0 & 8.7 \\
2.5 & 7.0 & 14.4 & 46.6 & 29.2 & 31.4 \\
0.9 & 2.5 & 6.1 & 7.0 & 21.0 & 19.9 \\
0.5 & 0.6 & 2.4 & 4.0 & 7.2 & 26.2
\end{tabular}

Sources: 1960 PUMS, 1/1000, and 1940 PUMS, 1/100, sample-line women only

Notes: The sample includes white women, currently married for the first time, whose husbands were present in the household. Years of schooling is completed years. 
Table 4: Husband's income as a Function of His Education and His Wile's

Dependent variable: Log of husband's annual wage, salary, and self-employment income

Husband's characteristics

Potential experience

Wives, 30 to 39 Years

Wives, 50 to 59 Years

Potential exp. squared

$\times 10^{-3}$

Years of schooling

8

9 to 11

0.0336

0.0202

(7.14)

$-0.692$

(1.67)

$(-6.90)$

$(-2.83)$

12

0.0811

0.209

(7.89)

0.276

13 to 15

(10.3)

0.426

(13.1)

$\geq 16$

(18.1)

0.0541

(1.58)

0.116

(3.00)

0.149

(3.37)

0.216

(3.87)

0.490

(8.53)

Wife's characteristics

Years of schooling

8

0.137

(4.13)

0.0851

9 to 11

0.222

(7.45)

0.234

(7.98)

13 to 15

0.254

(7.21)

$\geq 16$

0.309

(7.70)

0.0123

(3.24)

0.0757

(2.32)

0.150

(3.81)

0.159

(3.82)

0.260

(5.28)

0.138

(2.17)

Children ever born

Married in college

6.294

$-0.00780$

$(-1.44)$

0.0281

(0.34)

Constant

6.716

(25.7)

$\mathbf{R}^{2}$

0.34

Number of observations

7733

\subsection{5}

4202

\section{Source: 1960 PUMS}

Notes: The sample includes white women, currently married for the first time, whose husbands were present in the household and who were also married for the first time. The sample is further restricted to husbands whose implicit wage exceeds one-half the minimum wage in 1960 (ө.g., annual earnings > $\$ 1000$ for those employed z 50 weeks), unless they reported income from self-employment for which the restriction is that husband's income $>0$. Other variables included: urban, metro, city, region, and weeks worked using census grouplngs. The omitted dummy variable for education is 0 to 7 years. Years of schooling includes completed grades only. "Married in college" equals 1 if the woman married while attending college or in the year of her graduation or leaving college and her husband attended college. t-statistics are in parentheses. 
Table 5: Computing the Indirect Return to Coilege through the Marriage Market (for white women, 30 to 39 years in 1960, currently married for the first time)

Change in the (log) annual income of a woman's husband from her four years of college rather than her high school graduation:

(1) Due to a change in the probability of her marrying a husband of education level $i$ :

0.222

$66.5 \%$

(2) Due to a change in husband's income within his educational level:

0.075

22.5

(3) Due to the "early bird" effect, that is a change in husband's income from marrying in or just after college:

Total Change: $\Delta \ln Y_{h 1}=$

0.334

100.0

Notes: The regression in Table 4 contains husband's characteristics $X_{h}$, wife's characteristics $X_{w}$ and educational levels for each, $S_{h}$ and $S_{w r}$ it is given by:

$$
\text { en } Y_{h}=\alpha X_{h}+\Delta X_{w}+2 \gamma_{j} S_{h j}+2 p S_{w j}+c_{1}
$$

where both $S_{h}$ and $S_{w}$ are dummy variables for the 6 educational attainment groups. Thus, the income of a husband of educational level $i$ who is married to a woman who is a high school graduate (group 4) is given by:

$$
\ln Y_{h}=\left\{\gamma_{1}+\cdot\right\}+p_{4} \text {. }
$$

and that for a woman who is a college graduate (group 6 ) is given by:

$$
\text { en } \gamma_{h}=\left\{\gamma_{i}+\cdot\right\}+p_{B} \text {. }
$$

where $p_{4}$ is the coefficient for a wornan who is a high school graduate and $p_{6}$ is that for a college graduate. The probability that a woman of schooling level j marries a husband of schooling level $i$ is:

$$
\operatorname{Pr}\left(S_{h}=|| S_{w}=D\right. \text {, }
$$

which is given in part of Table 3. Thus the mean income for the husband of a high school graduate is: and that for a college graduate is:

$$
\text { en } Y^{*}{ }_{N}=\Sigma_{i} \ln Y_{w}^{4} \cdot \operatorname{Pr}\left(S_{h}=|| S_{w}=4\right) \text {, }
$$

$$
\ln Y_{W}^{* B}=\Sigma \text { en } Y_{w} \cdot \operatorname{Pr}\left(S_{h}=i \mid S_{w}=6\right) \text {. }
$$

The change in en $Y_{h l}$ with an increase in wife's education from high school graduate to college graduate is given by:

The difference can be decomposed into:

$$
\Delta \ln Y_{h}^{*}=\ln Y_{h}^{* 6}-\ln Y_{h}^{* 4}
$$

$$
\begin{gathered}
\sum_{1}\left[\ln Y_{h w} \cdot\left\{\operatorname{Pr}\left(S_{h}=i \mid S_{w}=6\right)-\operatorname{Pr}\left(S_{h}=|| S_{w}=4\right)\right\}\right]= \\
\Sigma Y_{1} \cdot\left\{\operatorname{Pr}\left(S_{h}=i \mid S_{w}=6\right)-\operatorname{Pr}\left(S_{h}=i \mid S_{w}=4\right)\right\}
\end{gathered}
$$

and

(2)

$$
\Sigma_{i}\left[\operatorname{Pr}\left(S_{h}=i \mid S_{w}=6\right) \cdot\left(\ln Y_{h}^{0}-\ln Y_{h i}^{4}\right)\right]=
$$

A further source of change can added by considering the "earty bird" effect, that is the impact on the earnings of a woman who attended college from marrying during college or in the year she graduated. Let $\delta$ be the coefficient on "marry in college" in Table 4. The "earty bird" effect is, then, the value of $\delta$ times the probability a college graduate woman marries in (or just after) college, $\operatorname{Pr}\left(M=1 \mid S_{w}=6\right)$ : (3)

$$
\delta \cdot \operatorname{Pr}\left(M=1 \mid S_{w}=6\right) \text {. }
$$

\section{Sources: Tables 3 and 4. The parameter 8 is 0.49 .}


Table A1: College Attendance and Graduation Rates by Sex, for Cohorts Born 1875 to 1957

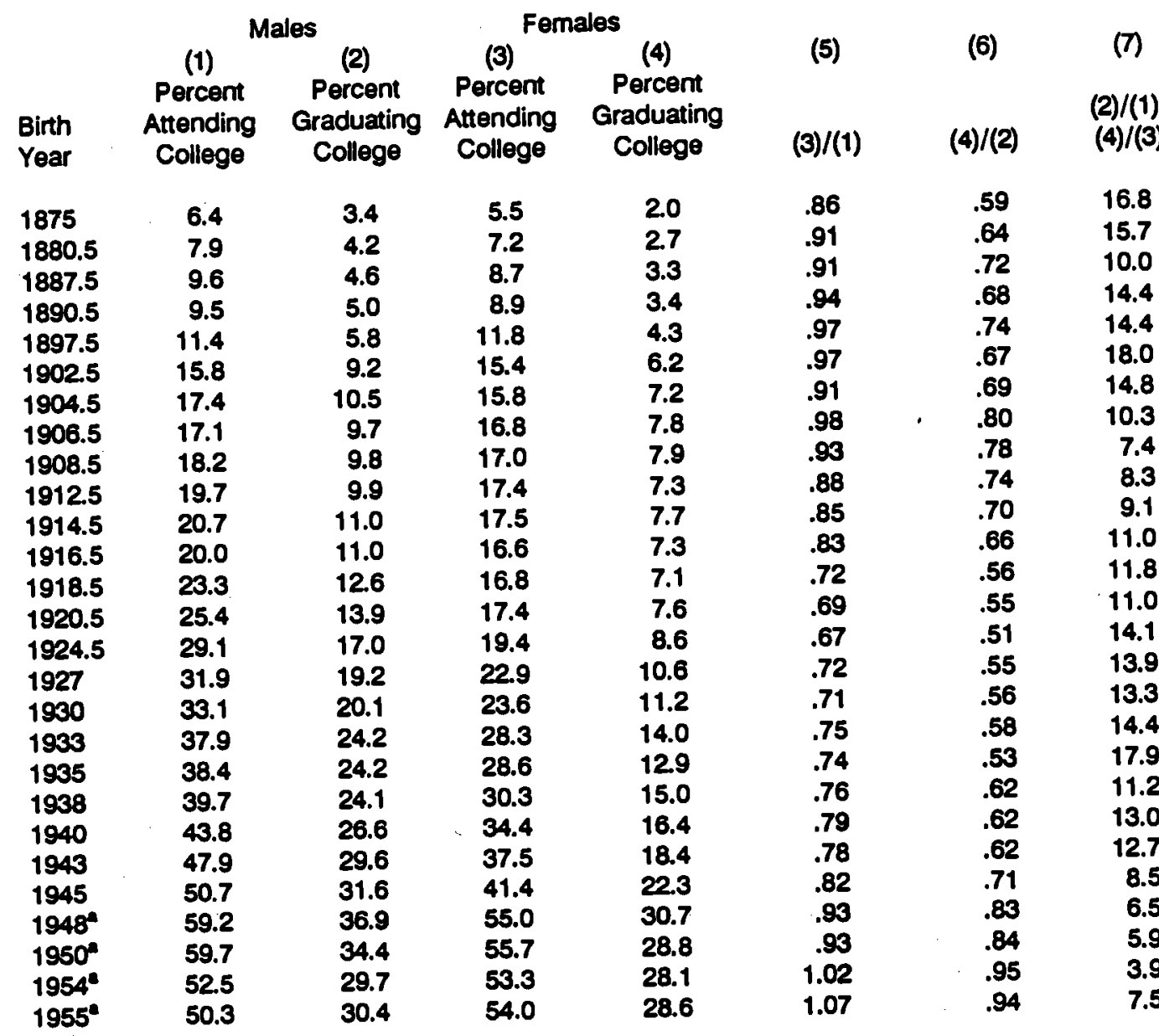

- Projections to 1995 or 1997 based on the experiences of the previous cohorts.

Sources: U.S. Bureau of the Census, Current Population Reports, Series P-20, Educational Attainment in the United States, various numbers, (Washington, DC: Government Printing Office, various dates).

Notes: In virtually all cases only the responses of individuals 45 to 54 or 55 to 64 years old were used. For cohorts born since 1945 projections were made to 1995 or 1997 on the basis of changes for the preceding cohort that was 35-39 (30-34) years in 1977 and 45-49 (40-44) years in 1987. 


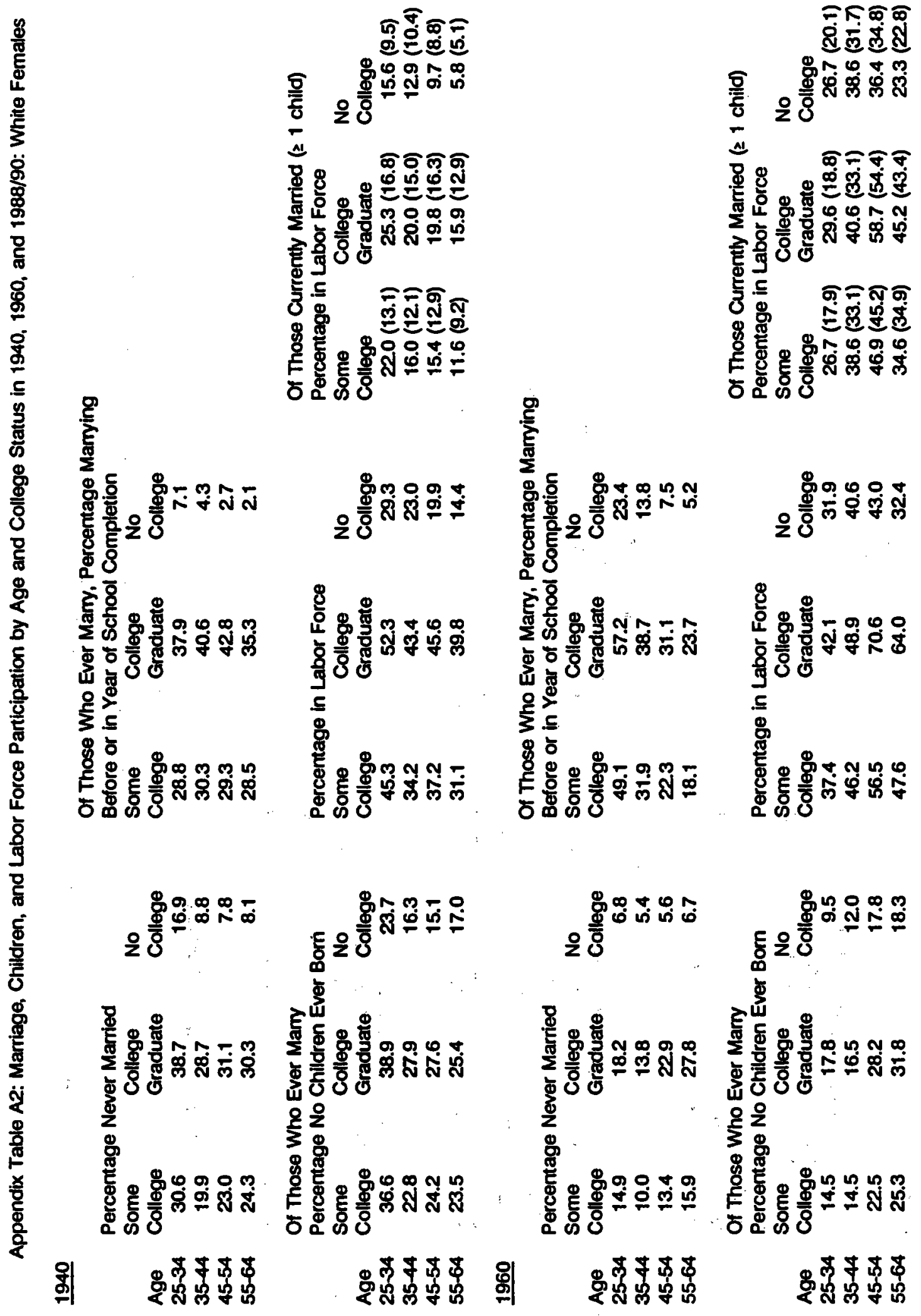




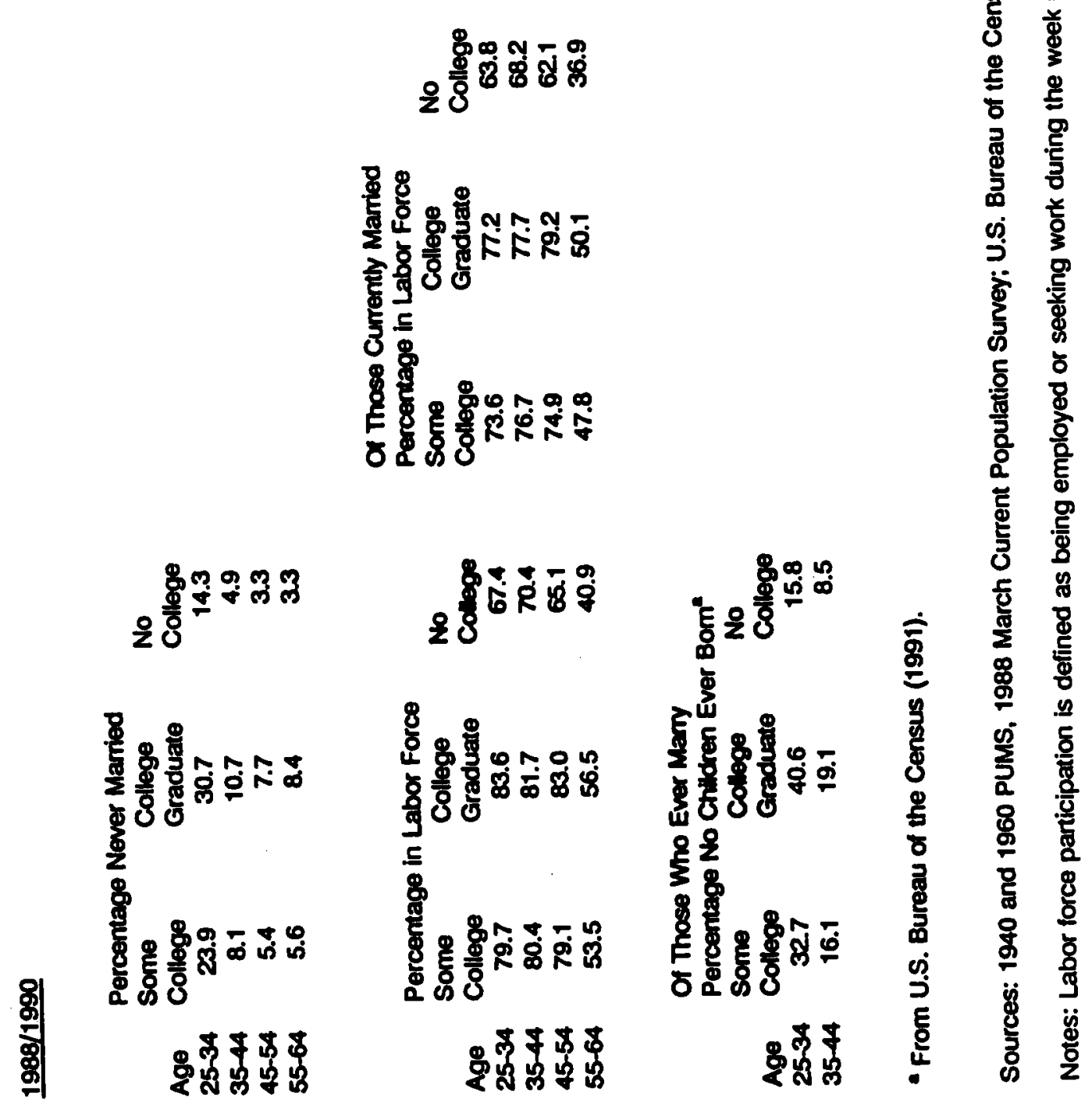




\section{References}

Cookingham, Mary E. (1984) "Bluestockings, Spinsters and Pedagogues: Women College Graduates, 1865-1910." Population Studies 38: 349-64.

Freeman, Jo. (1975) The Politics of Women's Liberation: A Case Study of an Emerging Social Movememt and Its Relation to the Policy Process. New York: Longman.

Freeman, Richard B. (1977) The Overeducated American. New York: Academic Press.

Friedan Betty. (1963) The Feminine Mystique. New York: Norton.

Goldin, Claudia. (1990) Understanding the Gender Gap: An Economic Histony of American Women. New York: Oxford University Press.

-1... (1991) "Marriage Bars: Discrimination Against Married Women Workers, 1920 to 195C." In H. Rosovsky, D. Landes, P. Higgonet, eds., Favorites of Fortune: Technology, Growth, and Economic Development since the Industrial Revolution. Cambridge, MA: Harvard University Press.

Newcomer, Mabel. (1959) A Century of Higher Education for American Women. New York: Harper and Brothers Publishers.

Preston, Samuel and John McDonald. (1979) Incidence of Divorce within Cohorts of American Marriages Contracted since the Civil War," Demography 16 (February): 1-25.

Shinn, Millicent Washburn. (1895) The Marriage Rate of College Women." The Century Magazine 50 (October): 946-48.

Solomon, Barbara Miller. (1985) In the Company of Educated Women. New Haven: Yale University Press.

U.S. Bureau of the Census. (1953) U.S. Census of Population: 1950. Vol. IV, Special Reports, Part 5, Chapter B, Education. Washington, DC: U.S. Government Printing Office.

(1955) U.S. Census of Population: 1950. Vol. IV, Special Reports, Part 5, Chapter C. Fertility. Washington, DC: U.S. Government Printing Office.

(1964) U.S. Census of Population: 1960. Subject Reports. Women by Number of Children Ever Born. Final Report PC(2)-3A. Washington, DC: U.S. Government Printing Office.

(1966) U.S. Census of Population: 1960. Subject Reports. Age at First Marriage. Final Report PC(2)-4. Washington, DC: U.S. Government Printing Office.

(1972) Census of Population: 1970. Marital Status. Final Report PC(2)-4C. Washington, DC: U.S. Government Printing Office.

(1973) Census of Population: 1970. Women by Number of Children Ever Born. Final Report PC(2) 3A. Washington, DC: U.S. Government Printing Office.

. (1975) Historical Statistics of the United States from Colonial Times to the Present. Washington, DC: U.S. Government Printing Office.

(1985) Census of Population: 1980. Subject Reports. Marital Characteristics. Final 
Report PC80-2-4C. Washington, DC: U.S. Government Printing Office.

(1991) Current Population Reports, Series P-20, No. 454, Fertility of American Women: June 1990. Washington, DC: U.S. Government Printing Office.

(1991a) Current Population Reports, Series P-20, No. 451, Educational Attainment in the United States: March 1989 and 1988. Washington, DC: U.S. Government Printing Office.

(various years) Current Population Reports, Series P-20, various numbers, Educational Attainment in the United States. Washington, DC: U.S. Government Printing Office.

(various years) Current Population Reports, Series P-20, various numbers, Fertility of American Women. Washington, DC: U.S. Government Printing Office.

U.S. Bureau of Education. (various years, 1900 to 1916) Repor of the Commissioner of Education. Washington, DC: U.S. Government Printing Office.

Office.

(various years) Biennial Survey of Education. Washington, DC: U.S. Government Printing

U.S. Department of Education. (1991) Digest of Educational Statistics, 1990. February. Washington, DC: U.S. Government Printing Office.

Otfice.

(various years) Biennial Survey of Education. Washington, DC: U.S. Government Printing

U.S. Department of Health, Education, and Welfare, Office of Education. (1960) Higher Education Planning and Management Data, 1959-60, by W. R. Bokelman. Circular No. 614. Washington, DC: Government Printing Office.

(various years, OFE) Opening (Fall) Enrollment in Higher Education. Washington, DC: U.S. Government Printing Office.

Printing Office.

(various years, Digest) Digest of Education Statistics. Washington, DC: U.S. Government

U.S. Department of Labor. (1966) College Women Seven Years after Graduation: Class of 1957. Bulletin of the Women's Bureau, No. 292. Washington, DC: Government Printing Office.

Van Kleeck, Mary. (1918) "A Census of College Women." Journal of the Association of Collegiate Alumnae XI (May): 557-91.

Woodhouse, Chase Going. (1932) After College, What? A Study of 6665 Land-Grant College Women. Their Occupations, Eamings, Families, and Some Undergraduate and Vocationa Problems. Bulletin of the Institute of Women's Professional Relations.

Woody, Thomas. (1929) A History of Women's Education in the United States. Vol. 2. New York: The Science Press. 